\title{
Everyday Mobility and Travel Activities during the first years of Retirement
}

\author{
Jessica Berg
}

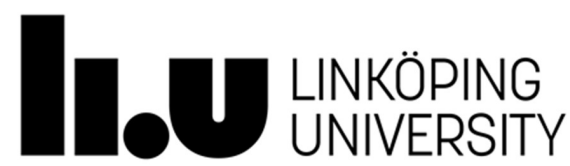

Linköping Studies in Arts and Science No. 671

Department of Social and Welfare Studies

NISAL (National Institute for the Study of Ageing and Later Life)

Norrköping 2016 


\section{Linköping Studies in Arts and Science • No. 671}

At the Faculty of Arts and Sciences at Linköping University, research and doctoral studies are carried out within broad problem areas. Research is organized in interdisciplinary research environments and doctoral studies mainly in graduate schools. Jointly, they publish the series Linköping Studies in Arts and Science. This thesis comes from the National Institute for the Study of Ageing and Later Life at the Department of Social and Welfare Studies.

Distributed by:

Department of Social and Welfare Studies

National Institute for the Study of Ageing and Later Life (NISAL)

Linköping University

60174 Norrköping

Jessica Berg

Everyday Mobility and Travel Activities during the first years of Retirement

\section{Edition 1:1}

ISBN 978-91-7685-829-5

ISSN 0282-9800

\section{(C) Jessica Berg}

Department of Social and Welfare Studies 2016

Cover design: Jessica Berg and Karin Andersson, VTI

Photo: Hejdlösa bilder

Printed by: LiU-Tryck, Linköping 2016 


\begin{abstract}
Mobility is central to living an independent life, to participating in society, and to maintaining well-being in later life. The point of departure in this thesis is that retirement implies changes in time-space use and altered routines, which influence demands and preconditions for mobility in numeorous ways. The aim of this thesis is to explore mobility strategies and changes in mobility upon retirement and how mobility develops during the first years of retirement. A further aim is to provide knowledge of the extent to which newly retired people maintain a desired mobility based on their needs and preconditions. The thesis is empirically based on travel diaries kept by newly retired people, and qualitative interviews with the same persons, and follow-up interviews three and a half years later. The results show that mobility is a way of forming a structure in the new everyday life as retirees by getting out of the house, either just for a walk or to do errands. Many patterns of everyday life remain the same upon retirement, but the informants also merge new responsibilities and seek new social arenas and activities. As a result, the importance of the car have not changed, but it is used for other reasons than before. After leaving paid work, new space-time constraints are created which influences demands for mobility. The study further shows that "third places" become important, especially among those who live alone, as they give an opportunity to being part of a social context and a reason for getting out of the house. The follow-up interviews revealed that declined health changed the preconditions for mobility. Daily walks had to be made shorter, and the car had to be used for most errands to where they previously could walk or cycle. However, mobility can also be maintained despite a serious illness and a long period of rehabilitation.
\end{abstract}

Keywords: ageing, retirement, mobility, travel activities, place, timegeography, interviews, travel diaries, qualitative longitudinal analysis. 



\section{Acknowledgements}

Many people have contributed to this thesis and supported me through the process of pulling this together. First of all, I want to thank my main supervisor, Jan-Erik Hagberg. You have the ability to grasp the most interesting results in my work, which helped me to constantly improve the thesis and to move forward. Thank you for sharing your experiences and knowledge of ageing research, for valuable comments on my texts and for always showing a genuine interest for my study.

I also want to thank my co-supervisors, Marianne Abramsson and Lena Levin. Marianne, thank you for all your wise comments and advice, and your genuine enthusiasm and engagement in my work. You have always encouraged me in my writing process, not least in the process of writing in English. Lena, thank you for your support throughout my research and writing, for your careful reading of my texts and for helping me to think strategically. I also want to thank you for always believing in me, and for considering what is best for my thesis and my future career.

Jan-Erik, Marianne and Lena, after each and every one of the meetings we have had, I always found new inspiration and knew exactly what I needed to do next. It has been fun!

To all the informants who have participated in the study by sharing your experiences, thoughts and writing diaries - Thank you!

Many thanks to VTI (The Swedish National Road and Transport Research Institute), VINNOVA (Swedish Governmental Agency for Innovation Systems) and the Swedish Road Administration, for financially supporting the studies and this thesis.

I owe many thanks to my colleagues at NISAL for contributing with fruitful discussions on ageing research, for all valuable advice throughout my work with this thesis and for maintaining a pleasant research atmosphere. Anna Martin, thank you for all administrative support. I especially want to thank my present and former Ph.D. student colleagues at NISAL for your good advice, friendship and happy moments together. 
I am fortunate to be part of a research group at the Mobility, Actors and Planning unit (MAP) at VTI. Thank you, everyone at MAP for your comments on my texts, for sharing your experiences of being a Ph.D. student and a researcher, and for all your great support and companionship. A special thanks to Åsa Aretun for your encouragement and willingness to support me in many different ways during the final phase of thesis writing. A special thanks also goes to Hans Antonson for all your practical advice concerning the process of writing and submitting papers.

I would like to thank the commentators who had given constructive comments on earlier versions of this thesis at the 30-, 60-, and $90 \%$ seminars. I also want to thank the members of the Time-geographical Network for giving me feedback on my ideas throughout the analysis work. A special thanks to Katerina Vrotsou who has helped me to visualize the travel diaries. Thanks also to Chris Kennard at Anchor English and Monica Lomark at VTI for proofreading services.

My friends and colleagues at VTI, Birgitta Thorslund, Jan Andersson, Jonna Nyberg, Magnus Hjälmdahl and Therese Jomander: You turn an ordinary working day into an unusually fun day. Thanks for all wonderful conversations and laughter, and for your friendship.

I would like to express my heartfelt gratitude to my parents Libuše and Kent and my sister Gabriella. You have taught me to be goal-oriented and never give up. Thank you for being positive to everything I ever wanted to accomplish and for always believing in me.

Most of all, I want to thank my boys, Christer, Sam and Tim for the happiness you give me. Chrille, you have always been caring and encouraging concerning my studies and other projects that I wanted to realize. Thank you for giving me the support and time that I needed in order to realize the project of pursuing a $\mathrm{Ph} . \mathrm{D}$. 


\section{Preface}

This thesis is part of a larger study in a research project within ERA-NET 2007: "Keep Moving: improving the mobility of older persons" and the part study Sentrip - Senior Life Transition Points. The point of departure for Sentrip was European transport research which shows that important key events or transition points during the life course are of central importance as regard mobility and choice of modes of transport among older people. Three countries were involved in Sentrip: The Netherlands, Austria and Sweden. VTI (The Swedish National Road and Transport Research Institute), LTH (Faculty of Engineering, Lund University) and WSP Group participated in Sentrip from Sweden. The project was financed by VINNOVA (Swedish Governmental Agency for Innovation Systems) and the Swedish Road Administration. 


\section{CONTENTS}

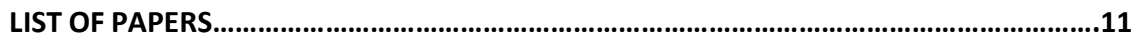

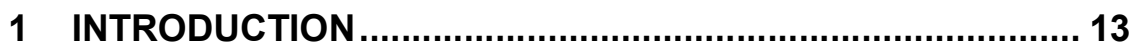

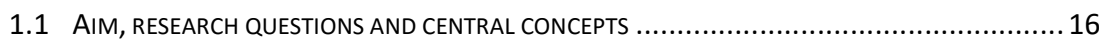

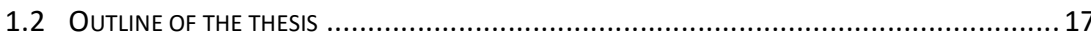

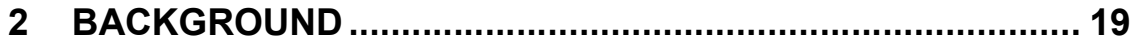

2.1 THE RETIRED POPULATION IN SWEDEN AND THE POST-WORLD WAR II GENERATION .............. 19

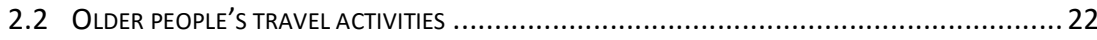

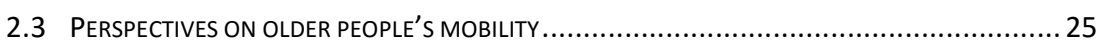

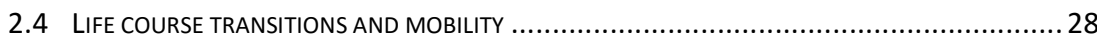

3 THEORETICAL FRAMEWORK ........................................... 31

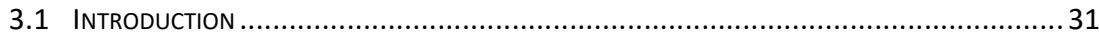

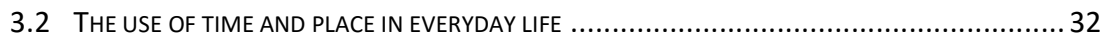

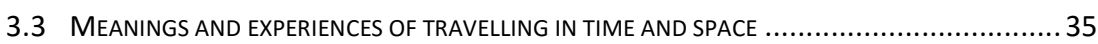

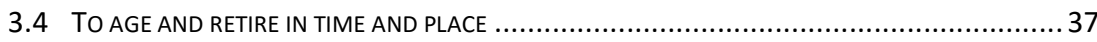

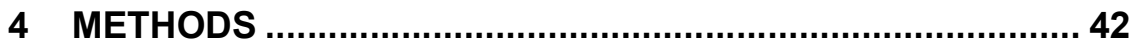

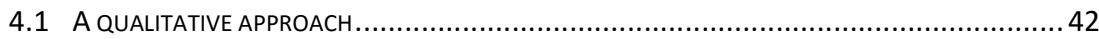

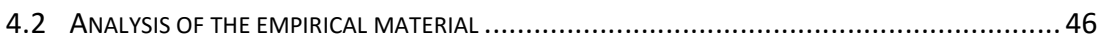

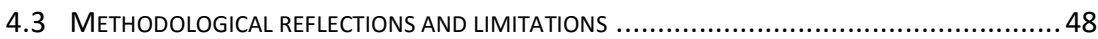

$5 \quad$ SUMMARY OF PAPERS …............................................... 52

6 SUMMATIVE DISCUSSION............................................... 57

6.1 THE IMPLICATIONS OF EXTENDED FREE TIME ON MOBILITY AND TRAVEL ACTIVITIES .................57

6.2 TIME-SPACE CONSTRAINTS FOR MOBILITY AND ACTIVITY PARTICIPATION ............................59

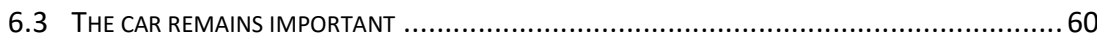

6.4 MULTIPLE TRANSITIONS AND CHANGES IN MOBILITY OVER TIME ....................................... 63

7 CONCLUSION ..............................................................66

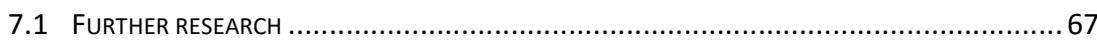

8 SUMMARY IN SWEDISH......................................................69

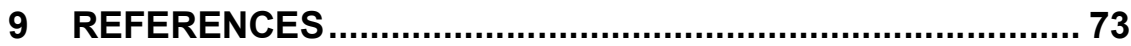

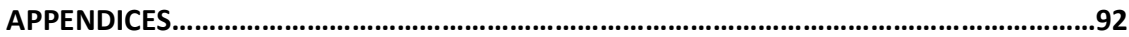




\section{List of papers}

\section{Paper I}

Berg, J, Levin, L, Abramsson, M and Hagberg, J-E. Time to spare Everyday activities among newly retired people in a middle sized city. Submitted.

\section{Paper II}

Berg, J, Levin, L, Abramsson, M and Hagberg J-E (2014) Mobility in the transition to retirement - the intertwining of transportation and everyday projects. Journal of Transport Geography 38: 48-54.

\section{Paper III}

Berg, J, Levin, L, Abramsson, M and Hagberg, J-E. (2015) "I want complete freedom": Car use and everyday mobility among the newly retired. European Transport Research Review 7 (31): 1-10.

\section{Paper IV}

Berg, J. Mobility changes during the first years of retirement. Submitted. 
Mobility is derived from people's needs and desires to carry out activities (Rasouli and Timmermans, 2014), and can also be enjoyed for the sake of travel in itself (Cao et al., 2009). Mobility is also central to living an independent life, to participating in society, and to maintaining well-being in later life (Mollenkopf et al., 2005; Ziegler and Schwanen, 2011; Nordbakke, 2013; Ziegler, 2012). At certain key events or transition points in life when changes in the everyday structure occur, changes in mobility needs and transport mode preferences might follow. Retirement is such an event that implies changes in the use of time and space and altered everyday routines: there is no more travel to and from work, new social patterns are shaped, and the individual has more time at his or her disposal. The present thesis examines mobility strategies and travel activities in the transition to retirement. The focus is on the retiree's own perspectives and experiences of mobility and everyday life as a retired person. This has been explored through interviews with retired people on two occasions, during their first year of retirement and again three and a half years later. They also wrote travel diaries for one week preceding the first interview occasion. The informants lived in Norrköping, a middle-sized city in Sweden, which was chosen because it offers a wide range of services, activities and choices of transport. The study has been permeated by the time-geographical perspective, which concerns people's use of time and place, the resources they have and the constraints they face in order to carry out activities. Furthermore, it includes the patterns of contexts in which the activities are taking place (Ellegård and Svedin, 2012; Hägerstrand, 1970b). The timegeographical concepts; activities, projects, contexts, resources and constraints, are theoretically and empirically important in order to understand how mobility strategies and experiences of mobility are intertwined in everyday life.

The thesis is a contribution to the broad field of research on older people's mobility but with an emphasis on the "young old" and a group of older people that is relatively healthy, well-off and have the possibility to choose between different modes of transport. The characteristics of the generation studied, people born during the 1940 s, are more significant than their 
chronological age, although age norms and accepted notions of pensioners and older people are considered as they can have an impact on expectations of retirement (Grenier, 2011). The thesis also contributes to the literature on mobility biographies, which studies how demands for mobility change due to key events during the life course (Lanzendorf, 2003). Retirement as a key event has been relatively absent in research on mobility biographies. There are several complexities in relation to retirement that have potential consequences for the individual's time-space ${ }^{1}$ use and mobility. Shopping and service errands that previously had to be carried out after working hours, might, after retirement, be carried out at other times of the day or on various occasions during the day. The modes of transport that were used between home and the prior workplace might not be suitable or preferred for activities after retirement. Retirement might also mean a loss of social networks that were connected to the workplace (Van Solinge and Henkens, 2008; Barnes and Parry, 2004). The picture is further complicated by other events that may occur simultaneously or after some time, such as illnesses or change of residence. Although the spatiotemporal ties to the workplace end upon retirement, other constraints might come into force that affect mobility and travel activities; for some, being retired means increased responsibilities towards children or old parents, while for others it means possibilities for leisure activities and travel (Fingerman et al., 2012; Godfrey et al., 2004). Retirement also implies lower income and economic constraints for many households (Walker and Foster, 2006; Macnicol, 2015). Retirement is conceptualized here as an adjustment process in which the individual is searching for an everyday structure including activities other than paid work to fill the days (Adams and Rau, 2011). It may take time for such an everyday structure to be established after retirement. People can experience an imbalance in life when job requirements are replaced with other demands and few regular commitments (Jonsson, 2011). It is therefore relevant to

${ }^{1}$ The time-space concept explains how time and bridging of space interact as resources and constraints for human action (Hägerstrand, 1970a). 
study this phase in life longitudinally in order to understand how the process of adjustment affects the need for mobility and choice of transport.

In transport research literature in recent years, two particular ways of portraying older people can be discerned. One line portrays older people as active, commonly as frequent car users and with a high degree of mobility (Buys et al., 2012; Pillemer et al., 2011). This portrayal suggests that frequent car use among a growing ageing population will lead to increased environmental problems, but for the individual in the long run, decreased mobility once they have to give up driving. The other line of research emphasises that older people are a particularly vulnerable group in the transport system because of physical and cognitive decline (Dukic and Broberg, 2012; Scheiman et al., 2010) but that healthy older people should continue driving as long as possible to avoid dependency and isolation (Alsnih and Hensher, 2003; Siren and Hakamies-Blomqvist, 2005; Siren and Meng, 2013). Research on further training of older drivers (Nyberg et al., 2009; Hay et al., 2013) shares this perspective. On the basis of this dichotomy, a more nuanced image of older people is needed in transport policy and planning in order to create sustainable mobility in the future that meets their needs and preconditions. This thesis contributes to that image. 


\subsection{Aim, research questions and central concepts}

The overall aim of the thesis is to explore individual's mobility strategies and changes in mobility upon retirement and how their mobility develops during the first years of retirement. A further aim is to provide knowledge of the extent to which newly retired people maintain a desired mobility based on their needs and preconditions. The following research questions are considered in accordance with the overall aim:

1. What out-of-home activities do newly retired people take part in and where are these activities carried out? In what respect, and for what reasons, do activities change or stay the same upon retirement? (Paper I)

2. What resources and constraints affect newly retired people's ability to travel when, where and how they want? What is the meaning and embodied experience of mobility among the newly retired? (Paper II)

3. To what extent is car transport used for everyday mobility in this phase of life and how is the car valued in comparison to other modes of transport? (Paper III)

4. How do mobility strategies develop during the first years of retirement? (Paper IV)

The time-geographical perspective permeates the study and underpins the collection of data, and is used to explore the taken for granted aspects of everyday life. Certain time-geographical concepts are used as tools in the analysis. Activities and projects take time and are influenced by resources and constraints and appear in social and geographical contexts. The concept of mobility is central to exploring the meaning that the individuals ascribe to travelling, and the experiences of it as more than getting from one place to another. These concepts are further developed in chapter three. 


\subsection{Outline of the thesis}

This thesis is written within the research field of ageing and later life and it consists of an introductory text, four papers, and a summative discussion. In this first chapter (the introductory text), the research problem, aim and research questions are presented. The next chapter, chapter two, presents a background which describes the main areas that are interrelated in the thesis and an overview of previous research on older people's mobility. That is followed, in chapter three, by a presentation of the theories that frame the papers. Chapter four describes methods, informants, and analysis and also provides critical reflections on the methods used. In chapter five, each of the four papers is summarised.

Upon retirement, when the individual gets more time to his or her disposal, it can be assumed that activity patterns change. Paper $I$ is based on this assumption and in this paper, we explore what activities newly retired people take part in and whether activities change upon retirement. Considered in this paper is also where activities take place and how social relations and environments influence activity participation. The paper is based on travel diaries and qualitative interviews with 23 newly retired people living in Norrköping, Sweden.

Paper II acknowledges that mobility is more than travelling from one place to another. This paper explores mobility patterns among the newly retired and the influence of space-time restrictions and on mobility. It further explores the meaning and embodied experience of mobility in the transition to retirement. This paper is based on qualitative interviews with 24 newly retired people in Norrköping (the same 23 as in paper I plus one more informant) and their one-week travel diaries.

Paper III is based on the same data as in paper II. As the car is the most used transport mode among older people, paper III investigates to what extent car transport is used for everyday mobility and how it is valued in comparison to other transport modes. 
The analysis of the first interviews aroused a curiosity of how everyday life as a retiree had developed and if mobility changes as time goes by, when they were settled as pensioners. Interviews were therefore carried out with the 24 informants, about three and a half years after the first interview, as well as three of their spouses that had retired since the first interview. Paper $I V$ is based on these follow-up interviews and explores how mobility strategies develop during the first years of retirement.

Chapter six provides a summative discussion of the main findings and of the contributions of the thesis to theory and practice. In chapter seven, a final conclusion of the results is presented, followed by suggestions for further research.

\section{Delimitations}

The study includes people who live in an urban environment. Norrköping was chosen as the geographical area for the study, to represent a middlesized city in Sweden, and because the city offers a variety of modes of transport. Because the informant group was to consist of people who had had a job and had experienced retirement, long-term unemployed and people who had been on long-term sick leave were not included. Another limitation (which was not planned in advance) is that older people with severe physical disabilities (i.e. in need of walking aids, wheelchairs) or intellectual disabilities were not included among those who agreed to take part. Trips abroad and long-distance journeys were not specifically studied, since they were not done routinely and as part of everyday life. Furthermore, since the study focuses on physical mobility and out-of-home activities, it does not explore how people replace physical mobility with virtual mobility, nor does it consider the significance of virtual mobility for out-of- home activities. 


\section{Background}

\subsection{The retired population in Sweden and the post-World War II generation}

Sweden, like other Western societies, has during the last few decades experienced a change in age structure, with an increased proportion of older people in the population (Statistics Sweden, 2009). The proportion of people 65 years or older was 19 per cent in 2012, which can be compared to eight per cent in 1900 and 12 per cent in 1950 (Statistics Sweden, 1999; Statistics Sweden, 2013a). Some years ahead, in 2020, 21 per cent of the population are expected to be 65 years or older. About 21 per cent of Sweden's population received old age pension according to statistics (Pensionsmyndigheten, 2014). In the year 2014 the average pension age ${ }^{2}$ was 64.5 years while the average exit age ${ }^{3}$ was 63.8 years (Pensionsmyndigheten, 2015a). Seventeen per cent of the population aged 65-69 years are working on average 26 hours per week. Employment has increased over the past ten years in Sweden among people aged 65-74 (SOU 2010:85). Higher education, better health, and a pension system that encourages further work after 65 years of age contribute to this fact. Meanwhile, the long-term unemployed and people with poorer health as well as financially independent people who can afford not to work are more likely to retire before the age of 65 .

Most of those who were born in the 1940s had retired by 2015 (Pensionsmyndigheten, 2015b). The informants who constituted the empirical base of this thesis were born during the 1940s, after the World War

${ }^{2}$ The average pension age refers to the age at which people receive an old age pension and includes income pension, supplementary pension and guarantee pension. From the age of 61 , it is possible to take a full state pension and still work (Pensionsmyndigheten, 2015a).

${ }^{3}$ The exit age indicates a predicted age when a person who is 50 years old today is expected to retire. 
II, and thus belonged to the same cohort, i.e. individuals who were born about the same time. This cohort is also often described as a generation as they have lived through the same social and environmental changes and thus have a joint history. According to a life course perspective, ageing is a dynamic process and is shaped by an interplay between the individual and changes in society and its structures (Elder, 1994). Riley (1998) outlines four principles concerning this interplay: (1) the life course principle suggests that no single phase in an individual's life can be understood apart from its antecedents and consequences. (2) According to the cohort principle members of different cohorts will change in different ways as they age, due to changes in society. (3) An individual's life is intertwined with the lives of other individuals, which influence and are influenced by social relationships. This is the principle of intersecting lives. (4) The principle of two dynamisms suggests that changes in people's lives and social structures are interdependent and neither can be understood without the other. Thus, to understand human behaviour and experiences of ageing and retirement, the social and cultural context that surrounds the individual must be considered.

Those born after World War II, are often described as specifically privileged, who have been co-creators of and made gains from the socioeconomic development that occurred during the second half of the 20th century in many Western countries (Thelin, 2009; Gilleard and Higgs, 2002). Several researchers point out that they have unique experiences that distinguish them from previous generations (Twigg and Majima, 2014; Coughlin, 2009; Lindgren, 2005). They were the first teenagers, a concept that was launched after the war when youth culture also appeared, and movies, magazines, clothing and music became important for expressing young people's identity (Sernhede, 2008). They have longer education (Eurostat, 2011; Statistics Sweden, 2012) and considerably higher disposable income than earlier generations (Statistics Sweden, 2013b). During their working life they have experienced reorganisation followed by further education, development of ICT, and globalisation but also psycho-social stress. Mothers to young children worked to a greater extent compared to their mothers and the children of those born during the 1940s became the first day-care generation. It can be assumed that what mainly distinguishes those who were born in the 
1940s from their parents' generation, concerning working-life, is the experience of the type of time pressure that is common today, when both parents work full time. The 1940s are often represented as an affluent generation belonging to 'the throw-away society' (Majanen et al., 2007; Lindgren, 2005; Hagberg, 2008). However, values regarding consuming changed during their upbringing from saving and owning to consuming and experiencing, which probably mirrors these modern days in general rather than a certain generation. The social and economic development and the diffusion of new technologies presupposed the demand and purchasing power of individuals (Hagberg, 2008). The Swedish consumption report however shows that the consumption patterns among those born during the 1940s are below average and that they show little interest in a gilt-edged life (Centrum för konsumtionsvetenskap, 2009). It is rather those born in the 1950s that push the consumption statistics upwards. Those born in the 1940s led the new health movement in the late 1960s when people in general became more aware of lifestyle hazards and health-promoting behaviours (Crawford, 2006; Lindgren, 2005). Health then became more of an individual responsibility, which resulted in an increased interest in fitness, jogging, and holistic health practices. During the years of their upbringing, environmental issues also became important. They are healthier and are expected to live longer with good health after retirement than their parent's generation. They will have the most beneficial pensions of all retired generations although there are differences between socio-economic groups (Lindgren, 2005). Some look forward to retirement and consider it a welldeserved time to rest. At the same time however, some are worried about no longer having a work place to go to.

Those born during the 1940s grew up during a time when the car became an increasingly important means of transport for many families. They have experienced significant improvement and development of the transportation system (Lundin, 2008; Coughlin, 2009). Compared to older generations, significantly more hold a driving licence and have access to a car in the household, which is mirrored in their everyday mobility (Siren and Haustein, 2013; Hjorthol et al., 2010). It can be assumed that upon retirement, they will engage more in the activities available and customize them to meet their 
interests and time schedules, compared to previous generations that have retired.

Newly retired people can be considered to be in the third age, which is defined as a phase in life that is characterised by increased freedom and independence, with stable finances, good health, and it is a time for leisure and pleasure (Laslett, 1991). The fourth age, in contrast, is characterised by dependency and decrepitude. Laslett (1991) argues that the third age should not be defined according to chronological age but according to functional, personal and social aspects of life that determine in which stage of life an individual is, but that the third age usually comes about after retirement. Gilleard and Higgs (2007) consider the third age as a cultural field that is defined and realized by the lifestyles of the cohorts born during the 1940s whose fulfilment after retirement is characterised by activity, individuality and consumption. The idea of the third age has been criticised. Krekula and Heikkinen (2011) state that the ability to live in the third age is limited to groups with access to resources such as health, money and education. A further criticism is that the distinction between the third and the fourth ages reinforces the homogenizing of older people as either healthy and active or sick and weak (Andersson and Öberg, 2006; Taghizadeh Larsson, 2009). It is important to emphasise the multiple implications and experiences of old age and the third age is one perspective of the life course, one that challenges traditional notions of old age as characterised by illness, decrepitude and dependency.

\subsection{Older people's travel activities}

In transport research, people are often categorised according to their chronological age, and thus ascribed specific needs based on their corresponding age-category. "Older people" as such a category often implies people who are aged 65 years and older. However, dividing people into groups (e.g. of 65-74 years old and 75 years and older) has become more common in statistics and literature on older people's transport. A problem with categorisations based on age is that several generations or age cohorts are portrayed as one homogenous group with similar needs and preconditions. However, some categorisation or definition is needed so that 
research on different groups in society can be carried out. The following section describes the travel activities among older people based on previous research and statistics.

The national travel survey is based on information about all travel-related movements that an individual makes during one day (Transport Analysis, 2012). Figure 1 shows what modes of travel are most frequent during one day by gender and age group. Most frequent among women in both age groups is walking while men most often travel by car. Women are car passengers to a greater extent than men and use public transport more. In the survey, 28 per cent of the women aged 65-74 had not been travelling during the day they were questioned, compared to 22 per cent among the men. Forty per cent of the women aged 75- 84 had not been travelling at all during the day they were questioned while the corresponding number for men in the same age group was 32 per cent. The national travel survey in Sweden includes persons aged 6-84. Thus, there is no data on national level for transport activities among people older than 84 years.

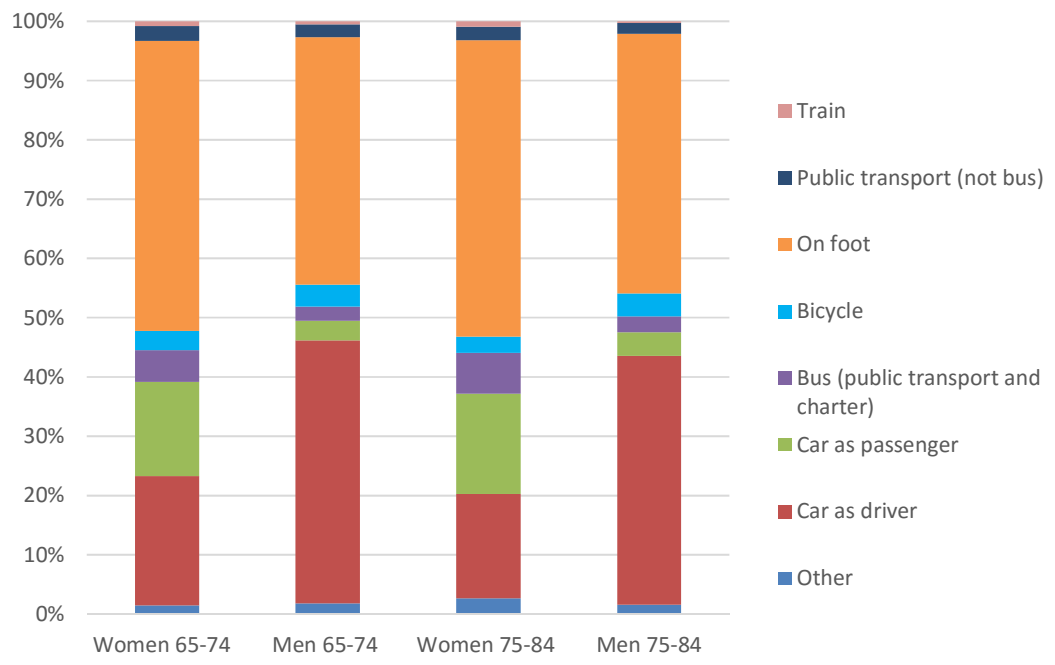

Figure 1 Most frequent mode of transport among women and men aged 65-74 and 75-84 during one day (Transport Analysis, 2012). 'Other' includes flights, boat, lorry, moped, motorcycle, tractor, taxi and special transportation service. 
Between 1978 and 2006, there was a marked increase in daily distance travelled among people over 65 years of age (all domestic trips except airlines) (Frändberg and Vilhelmson, 2011). People over 60 years of age in the Scandinavian countries made more trips by car in 2005 than comparable age groups did 20-25 years earlier (Hjorthol et al., 2010). This is partly explained by the fact that many more had driving licences and were car owners, especially among older women, compared to the earlier period. A few studies have paid special attention to transport mobility among those born during the 1940s (Miranda-Moreno and Lee-Gosselin, 2008; Siren and Haustein, 2013; Zegras et al., 2012; Westin and Vilhelmsson, 2011; Currie and Delbosc, 2010). Siren and Haustein (2013) show in a Danish study of individuals born in 1946 and 1947 that 43 per cent have reduced their travel by car compared to ten years ago while 17 per cent have increased their car use. The study showed that 91.4 per cent of the men and 76 per cent of the women drove a car every day or several days a week. Public transport was not much used. Thirty-two per cent considered that it was not very likely that they would drive a car at 80 years of age, while 21 per cent considered it very likely. Most of the participants considered it to be most likely that they would walk and cycle when they were 80 but that they would stay at home most of the time. More than 40 per cent considered that it was very likely or likely they would be using public transport. An Australian longitudinal study among "baby boomers" (born 1945-54) showed a small trend towards an increase in public transport use (Currie and Delbosc, 2010). The authors state that the future for public transport is not as bleak as research has previously shown but that the public transport system and urban density is of great importance for how public transport is used and valued among residents. Westin and Vilhelmsson (2011) compared travel activity patterns among young pensioners (65-75 years old) and older pensioners (76-84 years old). They found that the young pensioners were more satisfied with their mobility and made more trips than the older pensioners. Although trips to work disappear upon retirement, they are replaced by other trips that are relatively fixed in time and space. The authors stress the relevance of considering heterogeneity in analysis of ageing and travel activitiy change. 
A growing number of studies have presented different segments of mobility types based on factors such as attitudes, behaviour, and habits with the aim of making targeted efforts to the right target groups in transport planning (Haustein and Siren, 2015; Haustein, 2012; Cools et al., 2009; Jacques et al., 2013; Vij et al., 2013). Apparently, in those studies the emphasis on age is not always relevant. Haustein (2012) identified four mobility types among older people with consideration of both sociodemographic variables and infrastructure accessibility. The mobility types were differentiated according to their perceptions and actual restrictions in using different modes of transport. The restrictions concerned health, social status, infrastructure, and transportation system accessibility. The greatest restrictions were among those who were most socially disadvantaged. The 'captive car users' had limited access to public transportation and poor infrastructure, which led to car dependency and correlated with low mobility satisfaction. The 'affluent mobiles' had a high car availability and the largest social network. The 'selfdetermined mobiles' had good access to both car and public transport but did not feel pressure to be mobile all the time. The 'captive public transportation users', mostly women, had better infrastructural conditions so they could reach their destinations easily by walking or using public transportation. The results demonstrate the importance of taking both the personal and infrastructural prerequisites into account for understanding people's mobility.

\subsection{Perspectives on older people's mobility}

Older people's mobility in relation to transport has often been normatively and positively described in transdisciplinary research. In the literature, transport mobility is ascribed as a precondition for good health, quality of life and well-being (Bowling et al., 2003; WHO, 2002; Mollenkopf et al., 2005). Siren and Hakamies-Blomqvist (2009) found that maintaining one's personal lifestyle through mobility was an important component of wellbeing and that restrictions of independent mobility could be overcome by mental or technical compensation. The authors argue that the relationship between well-being and mobility is complex and related to compensation strategies and resources, lifestyle and the meaning of mobility. Also Ziegler and Schwanen (2011) argue that mobility and well-being are related in 
various ways. In a study of persons between 60 and 95 years old, they found that getting out of the house and socialising was an important aspect of wellbeing. Declined health and physical limitations, on the other hand, restricted mobility and social contacts and thus decreased emotional well-being. Schwanen et al. (2012b) showed how mobility can be an aspect of independent ageing. Mobility was triggered by not being dependent on others in order to get out of the house, being able to do things on one's own, self-reliance, and living alone, all of which contributed to independent living. The car was particularly important for enabling independence and autonomy in a way that public transport could not match. Transport and mobility as aspects of health have been highlighted in several studies. Supportive environments that enable walking and cycling for transport promote increased physical activity, decreased fuel emissions and noise, as well as increased traffic safety, all of which, in turn, promote both individual and public health (Sallis et al., 2004; Pillemer et al., 2011). Both the design of the physical environment and the characteristics of the social environment have been shown to have a major impact on opportunities for active transportation. These factors include high population density, lit roads, proximity to service and shopping, somewhere to sit down and have a rest, and social activities such as group walking (Chaudhury et al., 2012; Day, 2008). Health promotion is one of the Swedish transport policy goals for the environment since a reduction in the quality of life has been suggested to be a consequence of poor health (Regeringens proposition 2008/09:93).

Older people's mobility has also been studied from the perspective of accessibility, usability and barriers in a traffic environment, public transport included (Rantakokko et al., 2009; Walford et al., 2011; Ståhl et al., 2008; Wretstrand et al., 2009; Nordbakke, 2013). One important starting point for these studies is that older people who walk and use public transport, more than younger age groups, experience barriers in the physical environment that can cause not only falls and accidents but that may also discourage these older people from going out at all (Wennberg et al., 2009). Factors that have been identified as barriers in the physical environment are lack of snow removal, lack of benches to rest on, uneven pavement on walking paths, cyclists' and moped riders' behaviour and difficulties getting on and off 
buses (Ståhl et al., 2008; Walford et al., 2011; Rantakokko et al., 2009; Wretstrand et al., 2009). Social environments are also described as important aspects of older people's mobility. Wang and Lee (2010) found that older people who were able to see the streets and activities going on outside their window were more likely to go out than those who had windows facing towards a backyard. Also, walking correlated positively with the experience of safety from crime. Organised walks, opportunities to meet other people and stopping to chat while on a walk, as well as diverse social networks are also essential for older people's mobility (Mollenkopf et al., 2004; Chaudhury et al., 2012).

Another perspective in research on older people's mobility is the question of whether older people should continue driving, and the consequences of driving cessation (Oxley et al., 2010; Burkhardt, 1999; Sörensen and Hakamies-Blomqvist, 2000). Heikkinen (2008) states that older people's car driving has been viewed as problematic. She has studied how older people as a category in Swedish transport policy have been discussed, and has identified three periods. During the first period (1934-1967), old age and driving were considered to be a problem by the medical community. Mandatory driving tests were proposed but disputed by the medical profession as older peoples' driving was not a traffic safety problem. During the second period (1967-1991), "older drivers" were made into a category. Discourses about an increased risk of accidents among older people were put forward using the statistical U-curve ${ }^{4}$. Older people's mobility did not become prominent until the third period (1991-2006). In this period, older people were no longer seen as a traffic safety risk. Instead, mobility was discussed as a right for older people.

${ }^{4}$ The u-curve is a bar chart showing an increased risk of accidents among young and older car drivers, and a decreased risk among the age groups in between (Heikkinen, 2008: 170). The curve is based on the number of fatalities or injured in relation to the number of kilometres driven. 
In transport research it has been emphasised that the car is essential in order to allow older people to take part in social activities and be independent despite age-related health decline, and that drivers who are no longer able to drive become less mobile as a result of isolation and declined well-being (Liddle et al., 2012; Oxley and Whelan, 2008). Spontaneous trips or leisure travel, which have been shown to be important for quality of life, cannot be replaced by public transport (Davey, 2007). However, studies show that the consequences of driving cessation are not as negative for the individual as expected and that many say they actually experienced higher mobility after ceasing to drive (Oxley et al., 2010; Berg and Levin, 2011). Heikkinen (2008) states that mobility has been especially related to the right to drive and the importance of driving as long as possible, while being mobile using other modes of transport has not been highlighted to the same extent. Rather, a dichotomization between healthy and sick older car drivers has been made in which healthy older people should drive while sick older people should cease driving. Other modes of transport than the car have not been considered to the same extent as an aspect of active ageing. Recently, some researchers have suggested that an ageing population will lead to increased environmental problems, partly because the large cohorts that are retiring today use the car to a greater extent than other, more environmentally friendly modes of transport (Buys et al., 2012; Pillemer et al., 2011). That research is part of a larger discourse on sustainable mobility that emphasises the importance of behavioural influence and change of habits to reduce car use and carbon emissions in favour of more environmentally sustainable modes of transport (Schwanen et al., 2012a; Bamberg et al., 2011).

\subsection{Life course transitions and mobility}

A number of studies have focused on life course transitions, their impact on mobility, and what happens when the daily pattern changes for various reasons. It has been pointed out that in the event of changes in the everyday structure, people reconsider their possibilities (Van der Waerden et al., 2003; Verhoeven, 2010). Therefore, transitions or key events in life are of central importance for transport planning and decisions that influence people's choices. Salomon argues (in Verhoeven, 2010) that travel behaviour is affected when changes in one of many life domains occur. Salomon 
distinguished three domains in which changes can occur through the life course: lifestyle, accessibility and mobility. The lifestyle domain consists of demographic, professional and leisure careers. The accessibility domain refers to the careers of locations of employment, residence and leisure. The mobility domain consists of careers in car ownership, season tickets, holiday travel, and daily travel. Lanzendorf (2003) extended Salomon's model and developed the theoretical perspective of mobility biographies, which refers to "the total of an individual's longitudinal trajectories in the mobility domain and assumes that events in these trajectories exist or, put in other words, that at certain moments in an individual's life the daily travel patterns, the car ownership or other mobility characteristics change to an important degree" (Lanzendorf, 2003: 2). Müggenburg et al. (2015) further developed the mobility biographies approach based on previous research and identified four elements that strongly affect daily travel behaviour: (i) private and professional career; (ii) the adaption of long-term mobility decisions (such as car ownership and residential location); (iii) exogenous interventions; and (iv) other long-term processes that are not regarded as key events (e.g. age group, adolescent phase etc.). An overview of academic work on mobility biographies and related approaches can be found in Schoenduwe et al. (2015) and Müggenburg et al. (2015).

Transitions or key events that have been in focus in previous studies include, for example, when people become alone in the household, change of residence, education, changes in working conditions and workplace, as well as changes in family structure (Beige and Axhausen, 2012; Scheiner, 2007; Prillwitz et al., 2006; Stjernborg et al., 2014; Schoenduwe et al., 2015). Key events have been found to have effects on different types of travel behaviour such as car ownership, trip frequency, changed mode of transport, and commute distances (Oakil et al., 2014; Schoenduwe et al., 2015; Prillwitz et al., 2007; Van der Waerden et al., 2003; Scheiner and Holz-Rau, 2013). Beige and Axhausen (2012) conclude that decisions concerning long-term mobility usually take place early in life due to familial events such as education, employment and family formation. There are few studies of key events in late life in relation to mobility, and there is therefore little knowledge about how mobility decisions develop in later life. Mostly 
quantitative analysis has been used to study the impact of life course events on mobility (Verhoeven, 2010; Van der Waerden et al., 2003; Verhoeven et al., 2007). Quantitative activity-based approaches capture the complexity of travel demands and put travel activities in a social and spatial context unlike more traditional travel demand models where choice is understood as an expression of individual preferences and willingness to pay. However, there is a lack of detailed understanding of the time-space constraints that limit the individual, and the complexity of the interdependencies between individuals and the environment. Qualitative research that considers this complexity and studies people's own perspectives of mobility in life course transitions is scarce. This thesis complements previous studies of mobility biographies in at least two ways: first, it concentrates on a certain period in later life among people whose time-space constraints differ from those of people in the working population. Second, it uses a combined longitudinal and retrospective approach through qualitative interviews in two steps and travel diary method. This catches people's own perspectives on mobility as they adapt and respond to changing life situations. Qualitative interviews can highlight an individual's unique circumstances and the complexity in everyday life that otherwise is lost in quantitative analytical approaches. 


\section{Theoretical framework}

\subsection{Introduction}

The theoretical starting point here is that retirement, as a key event in later life, implies changes in time-space use and altered routines which influence demands and preconditions for mobility in numerous ways: there is no more travel to and from work, the individual has more time at his or her own disposal, and new social patterns are formed. Leisure activities, shopping and errands are no longer determined by the working life rhythm, and the individual can be more flexible in terms of choosing modes of transport (as a consequence of being able to organise his/her own time). At the same time, constraints might occur that limit the individual's actions, such as reduced income, new or increased commitments towards children and grandchildren, involvement in associations, or part-time work. Mobility is understood here as a result of peoples' needs and desires to carry out activities, in accordance with an activity-based time-geographical approach (Ellegård and Svedin, 2012; Rasouli and Timmermans, 2014). However, travelling as an activity in itself, such as taking a walk or going for a "Sunday ride" in the car, might also be a primary motivation for mobility (Cao et al., 2009).

Time-geography is an approach in which the relationship between activities in time and space is visualised and it shows how everyday life is organised and structured (Hägerstrand, 1970a; Hägerstrand and Lenntorp, 1974). Activities, projects, constraints, resources and contexts are timegeographical concepts that are used as tools in the analysis, and these are outlined in 3.2. In addition to the interest in how demands for mobility are created, it is important to consider the individual's own perspectives of the meaning and experiences of mobility at this time of life. Considering actual and experienced mobility is important in order to understand the conditions that determine whether the whole travel chain is possible to accomplish or not. In section 3.3, the phenomenon and concepts of mobility that are relevant to this study are outlined. This study concerns people who are of similar age and in a certain phase in life. Seen from a life course perspective, their experiences, habits, values and resources gained throughout life are important influences that they carry with them into retirement. Further, 
consequences of ageing affect the ability to travel and participate in activities. Theoretical perspectives on retirement as an assumed important transition in later life, and the process of adjusting to retirement are further developed in 3.4.

\subsection{The use of time and place in everyday life}

Individuals use their time carrying out activities that are always taking place somewhere and require different types of resources (Hägerstrand, 1970a). In this study of people's actual and experienced mobility, it is vital to consider that time, as a limited resource, sets limits for when, where and for how long activities can be implemented, and how far people can travel. The potential spatial reach is dependent on the modes of transport that are available. Even if time is available as a resource, people face different types of constraints that limit their freedom of action. Three types of constraints surround the individual and limit his or her freedom to implement activities (Hägerstrand, 1970a). Capacity constraints concern an individual's biological characteristics and his or her access to tools and ability to use them. Some constraints limit the ability to use time or compete for time. Eating and sleeping are limiting because they usually occur at specific places (home) and with a certain regularity. Other capacity constraints are the individual's physical and psychological abilities, material resources, as well as being aware of the existence of certain tools and services and knowing how to use them. To use public transport for example, demands knowledge of where to get information, where to get on the bus and how to buy a ticket. Coupling constraints concerns the fact that bundles of individuals, tools, material artefacts and the physical environment are interdependent, which is vital in order for production, consumption, socialising, and everyday life to work (Hägerstrand, 1970a; Hägerstrand et al., 1991). For example, some activities require coordination between family members or colleagues in a production chain. Other activities can only be performed at certain times during the day, such as shopping in stores (when the stores are open). Authority constraints are the laws, rules and norms and expectations in our institutionalized and societal context that make certain places or domains available only for certain persons and activities at certain times. A household, a housing cooperative, a workplace, or a local public transport system are examples of 
domains that organise activities and protect assets and resources, and limit access. The workplace may require an adaptation to certain working hours, and the public transport system may reschedule its timetables. An individual's daily schedule is thus dependent on a large number of decisionmaking entities that are beyond his or her own control. The three types of constraints collaborate in various ways. For example, an older person whose deteriorating health requires him or her to move closer to shops and services in order to continue to be independent, would require economic resources and perhaps access to "the right" social networks to gain access to an apartment in the city. Thus, the concept of constraints also clarifies what resources are available to an individual to allow that person to perform desired activities and projects (Ellegård, 1999).

According to the time-geographic perspective an activity is not necessarily important or targeted (Ellegård, 1999). It can also imply doing nothing. A series of activities that are necessary in order to achieve certain goals represents a project. The project of going to the gym might consist of packing a gym bag, driving, parking and changing clothes. Activities within a project are often carried out at various times. For example, packing the gym bag can be done the day before going to the gym. An activity can also be part of several projects. While driving home from the gym, one can stop at the grocery store as part of a dinner-making project. How projects occur, how they are carried out and by whom, and how they compete for space and resources is vital. All the activities that the individual carries out in sequential order during a period of time, normally one day, are part of an everyday context (Ellegård, 1999). Two activities seemingly unrelated to each other are in fact related when they appear in direct order, and this consequently affects how they are implemented and experienced by the individual. For example, the opening hours of the grocery store might affect how long one can stay at the gym, whether there is time to take a shower and a sauna, or whether one has to leave early in order to make it to the store before it closes. The everyday context also comprises routines and habits, that is, conditions that we do not always reflect upon. Some projects in an individual's life are not always carried out according to the person's own needs; rather, they are often carried out in a social context (Ellegård, 1999). 
The social context concerns how individuals and organisations collaborate in order to implement projects. For example, some activities within a project must be carried out by others or for the sake of others. Thus, the demands for mobility can be derived from other people's needs. The geographical context describes where activities are carried out, and for how long the individual has to travel to reach certain places. It also concerns the relation between activities, locations and movements. Some activities are always related to certain places while other activities can be implemented more or less anywhere.

\section{The contribution of time-geography to mobility research}

Understanding individual actions in relation to one's context is central to time-geography and relevant in this thesis, as travelling is intertwined with everyday life. Hägerstrand et al. (1991) emphasises the importance of studying the co-existence of people, society, technology and nature. $\mathrm{He}$ argues that if we take people out of their actual contexts to study behaviours and actions, much important information about how social and physical environments influence the individual will be lost. Ellegård (1998: 108) mean that time-geography is a valuable tool to visualise events and habits that are often taken for granted, by reflecting on "situations, relationships, links and positions" in the individual path or trajectory. This not only requires that a trajectory is considered when it manifests itself physically, but also requires reflection on what is hidden under the surface. Kjellman (2003) declares that she:

uses the time-geographical concepts in order to study changes that must occur when people for different reasons change their everyday life, change places and more or less change the routines they have set up their lives after /.../ Time-geography becomes a means to keep different projects in everyday life apart so that characteristics of each specific project can be studied while at the same time I place them in their larger context (Kjellman, 2003: 44). (Translation by the author).

The contribution of time-geography to this thesis can be seen in a similar way. The conceptual framework that time-geography offers is useful for 
studying different aspects of everyday life without losing the big picture, and for visualising the complex contexts that influence individual mobility and transport activities. Time-geography has been criticised for treating people as objects, driven by projects, rather than as individuals acting in a social context (Giddens, 1984), and for not taking individuals' feelings into consideration (Rose, 1993). Friberg (2003) on the other hand argues that feelings can be extraordinarily well depicted by using time-geography, and gives examples of time- geographical studies that portray the individual's mobility patterns as expressions of feelings. For example, Andersson (2001) shows how women who fear to use certain public places at late night, either do not use these places at all or choose other routes than they do during daytime. Since the origin of time-geography in the 1960s and 1970s it has been further developed and applied in transport research from several perspectives, e.g. time-space-fixity and accessibility (Schwanen et al., 2008; Neutens et al., 2012), gender differences in travel patterns (Kwan, 2000; Schwanen and de Jong, 2008), residential location (Ellder, 2014), and use of ICTs (Thulin and Vilhelmson, 2008). Many studies of time-space use have revealed how people in the work force deal with the balance between work, leisure and family. Older and retired people, whose everyday patterns are different from those who work and have small children, have not been included in such studies.

\subsection{Meanings and experiences of travelling in time and space}

The concept of mobility is often considered as synonymous with travelling or to be on the move. In recent years, mobility has come to be studied as a product and a producer of time and space, emotions, and power relations (Cresswell, 2006; Cresswell, 2010). In the introduction of the new mobilities paradigm, mobility is integrated as a dimension of social activities. The new mobilities paradigm challenges traditional approaches to travel behaviour research where travelling is studied as a "black box", separated from other spheres of social life (Sheller and Urry, 2006). The mobility paradigm is partly rooted in the time-geographical perspective. In this thesis, the approach to studying mobility as integrated in everyday life, similar to the 
ideas of the new mobilities paradigm, is to use time-geography as an analytical tool. According to Metz (2000), mobility as a concept has certain benefits since, besides actual movements, it also includes psychological advantages of getting out, the enabling of physical activity, and engagement in social activities, as well as knowledge of the potential trips that can be undertaken. Metz gives mobility a normative positive ascription, which is also, on a general level, the point of departure in this thesis. Mobility has been described as a precondition for well-being and independence, and as a central element of integration in society (Ziegler and Schwanen, 2011; Schwanen and Ziegler, 2011; Siren and Hakamies-Blomqvist, 2009; Risser et al., 2010). However, mobility as a concept needs to be differentiated as it is experienced in many different ways (Massey, 1991). To travel might be inconvenient or difficult for different reasons. Furthermore, some people are on the receiving end of mobility, and rely on other people's ability to be mobile, for example older people who have difficulties getting out of the house and need home care. Cresswell (2006) defines mobility as an entanglement of movement, representation and practice. Movement is the act of displacement between one place and another, which can be mapped or measured. Representation means that mobility is ascribed a certain meaning based on cultural norms and values. He writes: "Thus the brute fact of getting from A to B becomes synonymous with freedom, with transgression, with creativity, with life itself" (Cresswell, 2006: 3 ). The practice of mobility is what people do as they move, like walking or driving, and how it is experienced and embodied. The representations are often intertwined with embodied experiences of travelling and moving, and are discursively constituted. Sometimes moving is burdensome, while at other times we look forward to it. To walk, travel by bus or to drive a car can evoke different feelings and experiences depending on who we are, on our expectations and whether we are in charge of our own mobility or not. In this thesis, Cresswell's definition is useful for highlighting how mobility is intertwined with everyday life and the preconditions needed in order to carry out the whole trip chain. In order to capture newly retired people's own perspectives and experiences, there is a need for systematic analysis of their movements and their own descriptions. 
A few case studies have used the time-geographical approach to explore how mobility is emotionally experienced and intertwined in everyday life. From a gender perspective, Scholten et al. (2012) highlight how long-distance commuting women experience their everyday mobility and the balance between family and work. The authors caught the embodied experiences of travel, how time and space limit the women's choice of modes of transport but also release time to read, prepare, rest and readjust between different roles as mother, wife and professional. Schwanen and de Jong (2008) found how restricted opening hours at childcare centres, road congestion, and embodied moral notions of motherhood create restrictions for a working mother. In a study on mobility among low income, single mothers in San Francisco, McQuoid and Dijst (2012) explored how low wage jobs, sources of education, and various time-space restrictions such as locations of work and housing, gave rise to different emotions and travel behaviours which in turn had an impact on well-being and quality of life. Older people's mobility and travel activities have received little attention in studies using a timegeographical perspective. Stjernborg et al. (2015) is one exception. They explored the mobility of an older couple through interviews and travel diaries and found that time-demanding basic needs and limited access to modes of transport due to deteriorating health and location of residence implied capability constraints. However, implications of key events and transitions in later life and older people's adaptations and responses to such changes are yet to receive attention.

\subsection{To age and retire in time and place}

Retirement has long been seen as marking entry into old age (Vincent et al., 2006). However, the social and cultural meanings and experiences of growing old have changed in contemporary society (Grenier, 2011). Rather than being associated with illness, poverty and dependency, old age has during recent years been understood in terms of vigorous health, activity, participation, individuality and consumption (Walker, 2009; Katz, 2000; Twigg and Majima, 2014), mostly carried forward by the post-World War II cohorts (Gilleard and Higgs, 2000). It can therefore be assumed that the lifestyles and expectations on retirement of those who are retiring today will be different from their parent's generation. The potential impact that 
retirement and ageing has on mobility and travel activities among present and future retirees will be discussed in this section.

Retirement implies changes in time-space use and altered everyday routines: travel to and from work ends, new social patterns are shaped, and the individual has more time at his or her disposal. Shopping and service errands are no longer determined by previous working hours, but can be carried out at other times of the day or on various occasions during the day. The modes of transport that were used between home and the prior workplace might not be suitable or preferred for activities after retirement. Retirement might also mean new time-space constraints such as obligations to children, grandchildren or older parents (Szinovacz et al., 2001), volunteering or organisational memberships (Van den Bogaard et al., 2013), as well as reduced income, all of which set limits on the type and amount of activities that can be carried out, including travel (Macnicol, 2015; Walker and Foster, 2006).

Besides the time-space implications of retirement, the ability to travel and participate in daily activities is also affected by ageing. Physical and mental ageing have implications for balance, reaction, coordination and vision, which in turn have consequences for the ability to walk and cycle and to adapt to technical information systems that need to be managed in order to use public transport or to drive a car (Owsley et al., 2001; Vichitvanichphong et al., 2015; Whelan et al., 2006; Krogstad et al., 2015; Berg and Levin, 2011). However, the maintenance and design of the outdoor environment is crucial for the extent to which the impact of ageing contributes to reduced mobility (Hallgrimsdottir et al., 2015; Ståhl et al., 2008). The individual's social context obviously becomes affected by the decreased ability to be mobile. When access to transport opportunities decreases, the ability to participate in activities out-of-home or outside the near neighbourhood decreases as well, which might imply that the individual become dependent on others, for example for getting rides (Hjorthol, 2013; Schwanen et al., 2012b). Ageing is also a social and a cultural process. As outlined in 2.1, people age during a specific social time, in interaction between the individual and the social and cultural structures, where norms and beliefs about the meaning of old age and expectations on different events in later life form the 
individual and the lifestyle, as in the example of the cohorts born after World War II (Riley, 1998; Gilleard and Higgs, 2000; Grenier, 2011). The social and cultural background is of importance for how transport habits develop through the life course and how attitudes, values and norms regarding for example choice of modes of transport are formed.

Retirement is not solely an individual, discrete event. It occurs in conjunction with other transitions, and in connection with events in the lives of others (Grenier, 2011). Simultaneous transitions can occur when an individual gets seriously ill at the same time as he or she retires. Although the illness may have nothing to do with retirement, the experiences of the first period of retirement will most certainly be marked by the illness. Retirement may also have a direct impact on the life and result in changes in other life spheres. Changes in the geographical contexts might occur, such as a change of residence, perhaps because there is a need for cheaper accommodation, or because there are greater possibilities to choose where to live when one is no longer tied to a workplace. The individual is involved in different kinds of relations with family and friends and the interactions between his or her social worlds. The life course concept of linked lives highlights that the choices individuals make are always shaped by other people in their lives (Elder, 1994). Linked lives is understood in this thesis as a coupling constraint, which affects the individual's choices and opportunities to realize everyday projects. Mobility and travel activities are thus influenced by various factors: other people in an individual's life, whether one lives alone or with a partner, whether the partner still works or is retired, and demands from or dependencies on relatives, friends and acquaintances.

Retirement is studied here as a temporal process to which the individual adjusts (Macnicol, 2015). Potential changes in the life situation that comes with retirement are part of a process that might start even before retirement or that happens gradually during adaptation to the life as a pensioner. Several studies have described this process. One of the first was conducted by Atchley (1976). Using his terms, the first phase after retirement is described as the honeymoon phase (1) when people enjoy the free time and space, and make plans to do everything they did not have time to do before. This phase might be short or last for years; however not all people will experience this 
phase due to constraints of different kinds such as lack of finances, lack of activities or poor health. The disenchantment phase (2) is a period of letdown or disappointment after the honeymoon is over. How prolonged and heavy this period will be depends on how realistic the expectations of the retirement role were. Those who find it difficult to fill their own time, those who experience multiple transitions such as ill health, change of residence etc., or those who were heavily involved in their jobs are more likely to experience this period as depressing. In the reorientation phase (3), people try to find a new everyday structure and new routines, and to settle down as pensioners. In this phase people seek social relations, activities or rediscover previous hobbies. The stability phase (4) is characterised by predictability and by satisfaction. In this phase, people have found their new roles and know their capabilities and limitations. Even dealing with health decline in this phase can be routinized. Some people never enter this phase, according to Atchley, others enter right after the honeymoon phase. In the termination phase (5), a transition from a retirement role to an illness and dependency role takes place, where the retiree can no longer take part in activities and duties as before. Atchley points out that people can go back and forth between different phases, and that some phases are never entered, and some people can get stuck in one phase for the rest of their lives. Wang et al. (2011) outline a theory in which retirement adjustment is viewed as a resourcebased dynamic process, which suggests that as resources (physical, cognitive, motivational, financial, emotional and social) change during the retirement transition, the retiree's levels of adjustment will fluctuate. The above theories, seeing retirement adjustment as a process, have in common that the process is conceived as temporal and dynamic, and that the individual's level of adjustment fluctuates as resources change. This perspective is useful in this thesis as a basis for further elaborating on how mobility develops during the first years of retirement.

So far, the theoretical interest in studying the implications of retirement on mobility and travel activities has been outlined. To summarise, retirement releases time, which implies changes in patterns of activity and socialising. Expectations and experiences of retirement are strongly linked to one's social and cultural environment and history and the various contexts that the 
individual is tied to, as well as simultaneously ongoing transitions and social relations the individual has. In order to obtain knowledge on how demands for mobility are created at this period in life, how mobility is developed during the process of adjusting to a new life pattern, and in the light of simultaneous ageing, a longitudinal approach is used in this thesis. This approach is described in the next chapter. 


\section{$4 \quad$ Methods}

\subsection{A qualitative approach}

A qualitative longitudinal approach with two separate but related data collection methods has been used in this thesis. Travel diaries were expected to give answers to the questions of how and where people travel in their everyday life as pensioners, and qualitative interviews were going to explore changes in mobility after retirement, the meaning given to mobility, people's experiences of mobility and what resources and constraints are significant in order to travel when, where and how they want, according to the informants' own perspectives. Thus, the two data collection methods complemented each other.

\subsubsection{Informants}

Qualitative interviews were carried out in October 2011 with 24 persons (12 men and 12 women), and in March 2015 with 27 persons (14 men and 13 women). The starting point was that the informants should not have been retired for more than one year at the time of the first interview. This way, they were supposed to have had time to make some adjustments to the everyday life as a retiree but at the same time, would be able to recall how it was before. About three and a half years after the first interview, in March 2015 , the same people were interviewed again, in order to explore if and how their mobility had changed over the years. Three of these interviews were conducted with both partners in the household, partners that had retired since the first round of interviews and who agreed to participate. In total, 27 informants were interviewed. All lived in Norrköping municipality at the time of the first interview.

To study people in a middle-sized city was a strategic choice because of the access to a wide variety of transport modes. The Norrköping public transport system includes a tram service as well as local, regional, and national buses and trains, and there are walking and biking paths throughout the city. However, it can be expected that the car will be significant in a middle-sized 
city since the range of public transport is not comprehensive (compared for instance to larger cities).

In order to make contact with newly retired people, two organisations for pensioners were approached. They had access to information on people in the municipality who had turned 65 during the last year, regardless of whether they were members or not. One large employer in the municipality was also contacted in order to get hold of people who had retired recently. In total, 105 names and addresses were provided. However, it was not known which of those were retired. Letters to all of them was sent out with information about the study (appendix 1). They were contacted by phone a few days after the letters were sent out, and asked if they wanted to participate. Those who had not retired yet or, who had been retired for many years were excluded. Two informants were recruited through another study within this research project. In total, 24 informants who had retired during the last year agreed to participate in the study.

The follow-up interviews were organised as follows. Letters to all of those who had participated in the first interview, with an enquiry about participation, were sent out (appendix 5). The letter was followed up with a phone call and all the informants agreed to participate again. Five informants had partners that had retired since the last interview and these partners were asked if they would like to participate. Three agreed to this, and two did not have time to participate. Table 1 presents background information about the informants in 2011. They were between 63 and 67 years old (born between 1944 and 1948). Eight of them lived in rental multi-family housing, six in tenant co-operative multi-family housing, seven lived in semi-detached or terraced housing and three lived in single family housing. Seven informants also had a summer cottage. All but two had a driving licence. One of them did not have access to a car in the household. Seven informants lived alone, two of those were married but lived apart from their partners. The other informants were married/lived with a partner. 


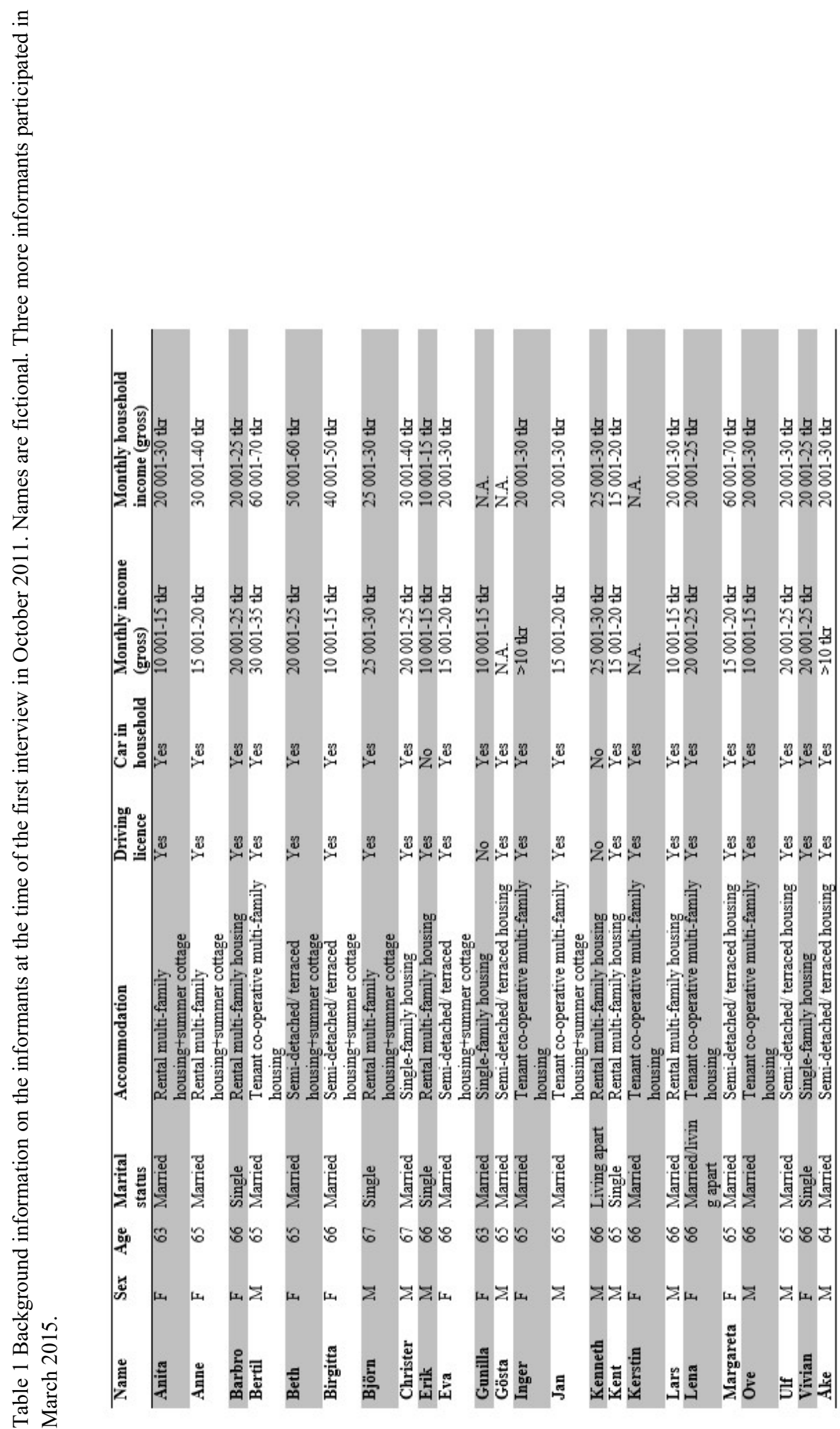




\subsubsection{Travel diaries}

Travel diaries were written in connection to the first round of interviews. All informants got a travel diary that was designed beforehand by the researcher (appendix 3). Information on how the diary was to be filled in was given both over the phone and in a letter accompanying the diary (appendix 2). The informants were asked note down every out-of-home trip made on foot, by bicycle, by public transport, and by car or other vehicles (even when they got a ride from someone) over one week in October. Thus, the weather conditions were equal for all informants. Ellegård et al. (1999) argue that diaries should be written over at least one week in order for the researcher to be able to find weekly rhythms. Each journey was supposed to be written down in order to discern a transport pattern. One journey can consist of several partial trips e.g. from home to the store (first trip), from the store to the kindergarten to pick up the grandchildren (second trip), from the kindergarten back home (third trip). By documenting all trips, it could be seen how they combined transport modes, how much time each trip took, how much time they spent in each place, and at what times during the day they were away from home. The travel diaries also worked as a basis for starting the interviews, with discussions about the trips that had been carried out and places the informants had visited during the diary week. Furthermore, it was desirable to find out if there were any trips that they had not been able to carry out for some reason.

\subsubsection{Qualitative interviews}

The first round of interviews were conducted one to two weeks after the informants had filled in the diaries. Kvale et al. (2009) use the metaphor the prospector (malmletaren) which can describe how the interviews were carried out. A prospector searches for certain knowledge and experiences and tries to extract this from the informants. The research questions that are based on the theoretical framework were the starting points when designing the interview guide. The questions were retrospective and prospective in character (appendix 4). Before the interview started, the informants filled in a form to give background information (table 1) (only at the time of the first interview). After that, the informants and the researcher looked at the travel diaries together and discussed 
the diary week day by day. The interview guide was semi-structured with a number of questions on each theme and follow-up questions that were asked in order to encourage the informants to develop what they had said or expand on certain things. The guide was used as a support and the order of the questions was changed depending on what the informants said. The interview guide for the second interview was slightly shorter and brought up the same themes as the first interview. In order to capture changes, retrospective questions related to the first interview were asked, such as: "Last time we met you told me that you enjoyed being a pensioner/ being retired was boring. What do you think about being retired today?" "It is now more than three years since the first interview took place. You said then that your main mode of transport was the car. What is it today?" "If you compare your life with how it was when you had just retired, do you go out more frequently or less frequently?" The interviews were either conducted at the university campus in Norrköping, at a coffee shop in Norrköping, at a public library or in the informant's homes. Telephone interviews were carried out with two informants in the second round of interviews. Most informants preferred to be interviewed at home. Before the interviews started, all informants were informed that their names and other personal information would be changed to fictional names or omitted in all presentations of this study (in accordance with the principle of confidentiality). The interviews lasted between 40 and 90 minutes. The interviews in the second round were slightly shorter. The interviews were recorded digitally, with the consent of the informants.

\subsection{Analysis of the empirical material}

The first interviews were transcribed verbatim by the author, and the follow-up interviews were transcribed by a consultant. The interviews were analysed using qualitative content analysis, which is recommended when the researcher wants to gain more knowledge and understanding of a phenomenon by making "subjective interpretations" of the content in a text in relation to an analytical framework (Hsieh and Shannon, 2005: 1278). The material was systematically coded and categorised. Initially, the transcriptions were read to get a picture of what was being said. Parts of the text that answered the research questions were condensed into more comprehensive parts without changing the content or meaning. In this phase, the time-geographical concepts of activities, projects, constraints and 
resources were used to help sort the statements. Statements that could be interpreted as meaning and experiences of mobility were also searched for, such as sayings concerning feelings about walking, about going out in bad weather, the need to get out of the house, to have many errands etc. Graneheim and Lundman (2004) call this condensation of a text. The condensed text was then abstracted into codes and categories (Graneheim and Lundman, 2004). Categories such as "strategies for mobility" and "physical activity" were created in this process. Graneheim and Lundman (2004) point out that the difficulty in categorising is to find exclusive and exhaustive categories, i.e. codes that do not fit into any category should not fall outside the analysis, and two categories should not describe the same phenomenon, but one category might contain a number of subcodes. For the analysis of the second interviews, a comparison was made with the first interviews. Going back and forth between the first and the second interviews generated new categories such as "(bad) health creates demands for mobility" and sub-categories such as "learning to walk again" and "have to keep moving to stay healthy". As a practical support for encoding and managing the codes, MAXQDA 10 , software for qualitative analysis, was used.

The travel diaries were analysed using VISUAL- TimePAcTS, an application for visualising and exploring activity diary data (Vrotsou, 2010). This application is based on the time-geographic perspective and the name means VISUALisation of the Time that activities occur, the Places they occur, the actual performed Activities, the Technologies used while performing them, and the Social context in which they appear. The application displays the frequency of activities for 24 hours. The application was used in order to see at what times the informants travelled during one day, what activities they were engaged in before and after travelling, and what modes of transport they used. This created a picture of how transport was intertwined in everyday activities. Figure 2 exemplifies how various modes of transport were distributed during a period of 24 hours, for 18 informants. 


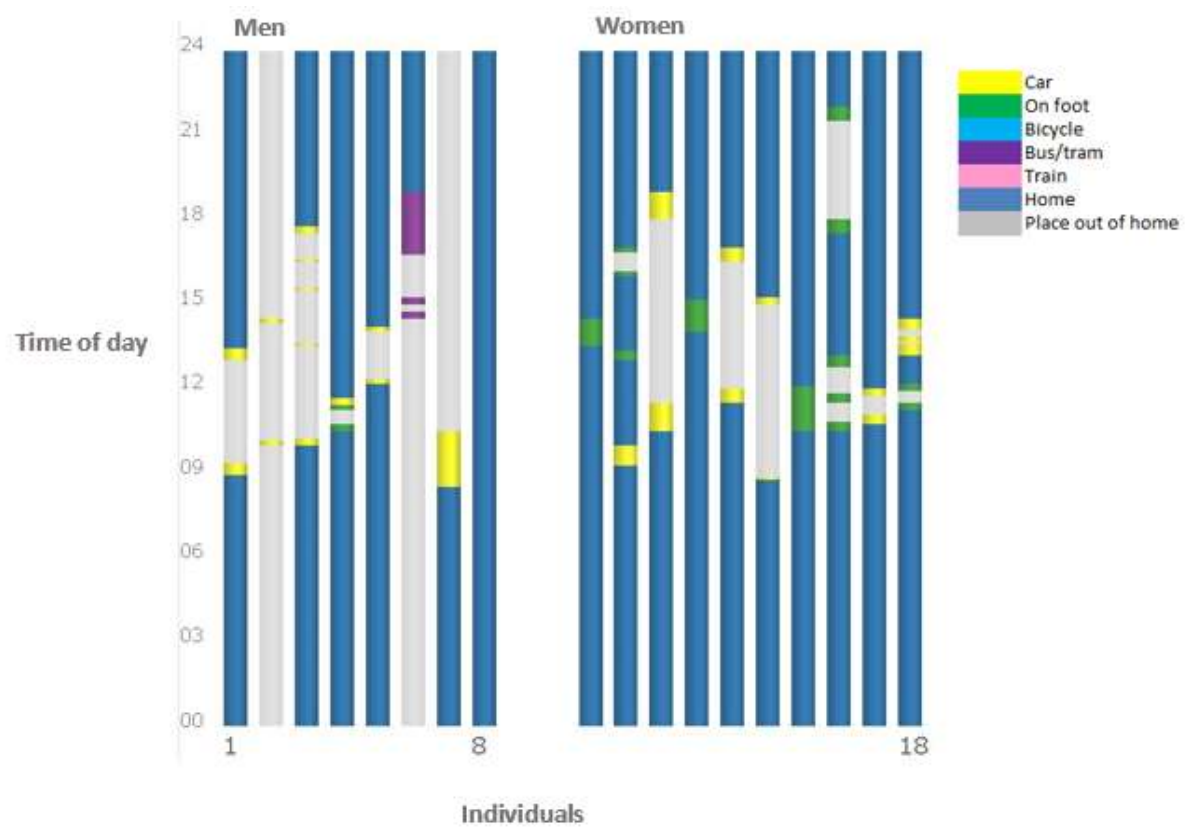

Figure 2 Example of how travel diaries can be visualised in Visual TimePAcTS. The colours represent different transport modes, as well as when the informants are at home and away from home.

The interviews conducted in 2011 and the travel diaries resulted in papers I, II and III. The analysis of the follow-up interviews in 2015 resulted in paper IV.

\subsection{Methodological reflections and limitations}

The sample consisted of people who had retired during the past year before the first round of interviews. The aim was to get a varied sample concerning gender. Those who agreed to take part also varied according to socioeconomic status, housing tenure, marital status and travel activities. There was no ethnic variation in the sample. All informants who agreed to take part were ethnic Swedes and they had retired from blue-, white-, or pink-collar jobs. The aim was not to interview only people who had a driving licence; among those 24 individuals who agreed to take part in the study, 22 held a driving licence, which does not differ much from the population in Sweden, where 89.8 per cent of those aged 48-66, 
and 89 per cent of those aged 67-79, hold a driving licence (BILSweden, 2014). It was desirable to interview both those who were socially active in associations such as pensioner's organisations, and those who were not socially active. As such no selection based on social activity was made from the lists provided. The lists of names that were provided consisted both of persons who were members and those who were not. In the outcome of the selected informants, there was a variation regarding their social life. During the interviews, it was revealed that all of the informants had friends and relatives with which they had regular contact. Some spent much time alone and some socialised with other people every day.

The benefit of the travel diaries is that they capture a weekly rhythm, and provide a basis for further discussion with the informants. The travel diaries can strengthen the reliability and validity of the study, provided that they have been correctly filled in by the informants. Writing down the actual movements reduces the possibility that the informants will answer according to what they think the researcher want to hear. In connection to the second round of interviews, no travel diaries were collected because the focus was instead on the informants's experiences so far of life as retirees and other key events in relation to mobility. The interview guide was constructed according to the research questions and the theoretical framework. The guide can also be seen as a tool to maintain a distance from the possible preconceptions of the researcher. Follow-up questions were asked during the interviews to ensure that answers were not misunderstood.

In this study it was irrelevant to study transport as separate events without considering the geographical and social contexts in which trips were made and the individual projects that generated the need to travel. Therefore, it was important to keep a holistic perspective on each informant's sayings, even if the encoding was carried out for the whole body of material. Dense and thorough descriptions have been given for certain cases in order to illustrate different transport patterns. Sayings have been placed in a context, and have been described in detail when relevant. By illustrating cases in this way, context-dependent knowledge was gained (Flyvbjerg, 2006). The complexity of everyday life is highlighted, which increases the understanding of the time-space constraints that an individual is experiencing, consciously or unconsciously. 
In writing the papers, the informant's own words were used as much as possible and citations were included in the text to facilitate understanding of how the interviews were interpreted. The authors went back to the transcripts and the recordings of the interviews when necessary to ensure that the informants' detailed statements were not misrepresented. In this way, the validity of the results was ensured because interpretations of the findings can be carried out by others. In order to strengthen the reliability of the results, all the authors of papers I, II and III read the transcripts of those cases that were considered to be typical for the whole body of material, and those cases that were considered as different (even the transcripts from the second round of interviews that resulted in paper IV). They then discussed how the interviews could be interpreted.

How are the results of the study relevant for newly retired people in general? Because the focus of the study is on a certain cohort of retired people who live in a Swedish urban context, it is important to be careful about generalising the results. All individuals are unique. This means that they all have different lifestyles, needs and interests, which makes generalisation in a narrow sense difficult. Knowledge from one or a few cases can have its own value, without generalising (Larsson, 2009), for example when one single case falsifies a universal truth. Provided in the four papers in this thesis, there is a description of the population that was studied, their social and historical background, and the characteristics of the cohort, and in which geographical and social context they live. Describing the informants' contexts as explicitly as possible and exemplifying them by presenting different cases, improves the transferability of the knowledge gained from this study to other, similar contexts or situations.

The process of adjusting to retirement, that is studied here, might imply changes across time. Such data are challenging to analyse since people's experiences and perceptions of different events and actions might have changed with the passage of time. Attention must be paid to the multiple and possible types of changes (Saldaña, 2003), which in this study can result from age- and life course-related experiences such as health decline, illnesses, birth of grandchildren, grandchildren becoming older, partner's illness or death and so on. Thus, it is difficult to isolate the effect of retirement on changes, which points to the complexities and difficulties of studying retirement since it is embedded in so many other changes 
in life. The process of adjusting to retirement is not a linear process. It can be interrupted and delayed, and people may return to earlier stages of adaptation depending on their different circumstances (Hörschelmann, 2011). It is therefore important to be careful when talking about changes in mobility and travel activities as a consequence of retirement as a key event in a longitudinal study. If changes are observed or expressed one must consider that further changes might happen after the study is finished. One must also be open to the fact that changes might not occur at all during the study process (Saldaña, 2003). Great care needs to be taken when speculating about future mobility and travel activities as people age. However, it is not only changes that retirement might imply that have been of interest here; a broader view is taken on what retirement means for the creation of mobility strategies and new habits, and consideration is given to whether, and if so how, a new everyday structure should be set. 


\section{Summary of papers}

\section{Paper I}

\section{Time to spare - Everyday activities among newly retired people in a middle- sized city.}

What out-of-home activities do newly retired people take part in and where are these activities carried out? In what respect, and for what reasons, do activities change or stay the same upon retirement?

The background of paper I is that as people retire, they will form new routines and everyday activity patterns in which new places will become nodes, and in which people other than those they have previously been associated with are involved. Knowledge about the expectations this generation has of retirement, its requests for activities and what they believe the urban environment should offer is important for informing decisions about how to create environments so that people can stay active and independent as they age.

This paper is based on analysis of travel diaries and 23 interviews. The results from the travel diaries show that shopping and association activities were most common during the weekdays, while recreational activities and socialising with family and friends mostly occurred during weekends. However, most time was spent at home. The interviews revealed that many of the informants searched for new social contacts and engagements in order to stay physically, socially and mentally active. There were several places in the informants' everyday lives that served as "third places", i.e. a social home away from home (Oldenburg, 1999). The shopping malls and market streets, the church for concerts and open lectures, and arenas for sports and training were third places that were visited by the informants, particularly the informants who lived alone. The third places were the main social arenas they had in their everyday lives. The present study shows how searching for such places is a part of the adjustment to being a pensioner. The conclusion of this study is that retirement is a stage in life when people change their activity patterns to a certain extent, but the nature of these patterns is dependent on a complex set of circumstances: what the individual wants to do, other people's needs and time schedules, other people's support, the geographical 
locations where activities take place, and the individual ability to overcome distances.

\section{Paper II}

\section{Mobility in the transition to retirement - the intertwining of transportation and everyday projects.}

What are the mobility patterns in the transition to retirement? How do time-space constraints influence mobility? What is the meaning and embodied experience of mobility among newly retired people?

Paper II contributes knowledge about how late life transitions, in this case retirement, influence mobility and transport patterns. The background of this paper is the premise that mobility is more than travelling from one place to another. Rather, mobility is imbued with feelings and meanings, and has certain benefits beside the actual movement. In the transition to retirement it can be expected that mobility patterns as well as the meaning of mobility change as the individuals search for other ways to organise everyday activities. The analysis, which is based on travel diaries and 24 interviews, revealed different and complex mobility patterns. Four cases illustrate this complexity. These cases exemplify how mobility in the transition to retirement is embedded in everyday life, routines and social relations.

The results show that everyday mobility is a way of forming a structure in the everyday life as a retiree by getting out of the house, either just for a walk or to do errands. The fact that the informants are no longer temporally and spatially restricted to a working life means that some put more effort into getting out and being active. They walk or cycle to get exercise, to maintain good health, to get fresh air, but also to get out of the house. The results reveal that for many, health is the most important individual project after leaving paid work. Taking care of one's health reflects a lifestyle that many people in this generation have had during their adulthood. Another finding is that retirement creates time-space constraints in several ways, which influences the informants' demands for mobility and choice of transport mode. Caring for grandchildren, volunteer work, and household responsibilities are such constraints. Other constraints that were 
identified were health, inadequate bus services, and relying on others to be mobile. However, many informants have resources that can be seen as strategies to overcome constraints, for example coupling (spouses and acquaintances), capability (being able to walk or bike around the city), and authority resources (the availability of shopping and service facilities). A question that arose from the analysis was whether the informants would maintain their walking and cycling habits in order to keep active and to get out of the house, even when they had settled as pensioners. This question is explored further in paper IV.

\section{Paper III}

\section{"I want complete freedom": Car use and everyday mobility among the newly retired.}

To what extent is car transport used for everyday mobility upon retirement? How is the car valued in comparison to other transport modes?

Many of those in the baby-boom generation (roughly 1945-54), who are retiring now have driving licences, and use the car to a great extent for everyday transport. This issue is discussed in paper III by exploring car use among recently retired people born during the late 1940s. The paper is based on travel diaries and 24 qualitative interviews.

Four main reasons why the car was particularly significant among the informants were revealed in the analysis, namely: 1) having many or heavy things to carry, 2) combining errands in different places, 3 ) accompanying others and offering support to others, and 4) recreation and vacations. The importance of the car does not seem to change upon retirement, albeit it is partly used for other reasons than before. The car saves time, both for the informants but also for others who need help or want a ride. The extended free time after retirement provides the ability to choose one's preferred mode of transport, which results in increased walking or cycling for many. However, according to the travel diaries, the car was the most used mode of transport during the diary week. Thus, using a combination of travel diaries and interviews, this paper reveals how the informants reason as regards their travel behaviour, but also how they actually travel. One conclusion of this 
study is that although the car was used more than other transport modes, being able to walk and cycle now that they had more time as retirees was highly valued. The findings from this paper indicate that urban residents who are retiring now and in the future are a key target group in transport planning when it comes to reducing car use in favour of slow modes of transport.

\section{Paper IV}

\section{Mobility changes during the first years of retirement.}

How do mobility strategies develop during the first years of retirement?

Already in paper II, the authors asked how mobility changes once the informants have settled as pensioners. This curiosity, and lack of knowledge about mobility development in later life, led to follow-up interviews in 2015, with the same 24 informants as in 2011, and three of their spouses who had retired since the first interview. This paper especially explores the process of adapting to life as a pensioner and how other changes (besides retirement) influence mobility and travel behaviour. The combined analysis of the first and the second interviews show that many had become accustomed to a life as a pensioner. Getting out of the house and being physically active were still important although the informants were not as stressed about filling the days with important activities as they had indicated at the time of the first interview. Declining health had changed the preconditions for mobility. For some, a consequence was that their daily walk had to be made a little shorter, or that the car had to be used for most errands to where they previously could walk or cycle. One case exemplified how mobility can be maintained despite a serious illness and a long period of rehabilitation. Other circumstances in life that influenced mobility were changes in family and social networks, change of residence, and when there were two pensioners in the household. Furthermore, actions to improve one's own mobility were exemplified by one informant who stopped walking and cycling and bought a car instead. The paper concludes that a number of factors have implications for how well people adapt to retirement. Resources include health, partners, friends, having a number of transport options to choose from, proximity to activities, shops and services, and empowerment. Those with poorer health, few financial resources, few or no engagements, and who are less empowered to take up new activities are less 
satisfied with their situation. Finally, seen from the perspective of this specific period, the results indicate four dimensions of mobility: (1) mobility as a means of carrying out activities which are needed and desired; 2) mobility as a resource for creating activities; (3) mobility as a leisure activity in itself, and (4) mobility as subordinate to staying at home. 


\section{Summative discussion}

One aim of this thesis is to explore mobility strategies and changes in mobility upon retirement and how mobility develops during the first years of retirement. A further aim is to provide knowledge of the extent to which newly retired people maintain a desired mobility based on their needs and preconditions. A special focus is on people in an urban environment. By conducting qualitative interviews and collecting travel diaries, the perspectives of newly retired people themselves are highlighted. This chapter provides a summative discussion of the main findings from the analysis of both the travel diaries and interviews.

\subsection{The implications of extended free time on mobility and travel activities}

What retirement involves was given different meanings by the informants in this study. The experiences of retirement were heterogeneous and complex, as also shown in previous research on retirement from different fields (Wang, 2007; Szinovacz, 2003; Muratore et al., 2014; Jonsson et al., 2000). In the present thesis, some specific features of the experiences of retirement can be discerned. Retirement was awaited and the informants enjoyed being in charge of their own time. Even though new constraints had appeared in terms of commitments to family and volunteer work, many said that they could do what they wanted to do. Mostly, as a first answer they considered that retirement had not implied any drastic changes; rather everyday life had gone on as usual. This result confirms the idea that people attempt to adapt to changes in life and try to maintain existing structures as they age (Atchley, 1999). Continuity was also found in a study of activity patterns among older people in six European countries (Fortuijn et al., 2006). The study found that at specific stages in later life, people disengage from activities that are physically or mentally demanding, rather than disengaging from activities in general. In the present thesis, it was found that the informants adapted their travelling according to their physical and mental abilities rather than giving up on activities that they had always engaged in. Furthermore, they had expectations about what to do in retirement. Whereas some had many plans, for example to take up household projects such as renovating and organising, others took one day at the time. Retirement brought feelings of boredom when there was 
nothing to do, when one did not know what to do, or for those who did not have anyone to spend time with. A planned activity that had not been done, either because they did not feel like doing it or because other things had prevented it, could be stressful. The extended free time that was made available upon retirement implied changes in travel activities and meanings of mobility. For some, retirement meant that they were no longer in a hurry. They could walk or cycle to activities, whereas they had driven before retirement when they had to juggle responsibilities of work and leisure time activities. Mobility had become an activity in itself. It had become a way of forming a structure similar to the working life rhythm. When travelling between home and the previous workplace they most often had to get to and back from work as quickly as possible. Upon retirement, errands and other activities were combined with physical activity, and sometimes this implied detours to the local store in order to turn the walk into a round of exercise. Staying mentally and physically active was a way to keep ageing and ill health at a distance. A question that came up after the analysis of the first interviews was whether walking and cycling for transport and exercise were popular due to "the charm of novelty" and would eventually subside. After the analysis of the second interviews it was noted that walking and cycling had subsided to a certain extent, often because health had deteriorated in various ways, but also because the informants did not feel as stressed about getting out every day and filling the days with beneficial activities. For some, mobility was desirable, and associated with positive, embodied feelings, while others forced themselves to go out, which sometimes implied that errands had to be created. Others could stay home all day most of the time. Margareta and John (paper IV) said that since they were both retired, it had become a major project to get out of the house and take a trip, so they stayed home on most days. Furthermore, as retirement implies the loss of a certain place and a loss of daily contact with colleagues, mobility had become a means to be social and escape from loneliness, especially among those who lived alone. Third places (Oldenburg, 1999) such as the shopping malls and market streets, the church for concerts and open lectures, and arenas for sports and training, had become important, as they provided an opportunity to meet other people and engage in something that is considered meaningful. The results presented in this thesis complements previous research on mobility biographies (Lanzendorf, 2003; Müggenburg et al., 2015). Most research within mobility biographies have analysed quantitative data and studied 
key events that occur earlier in life, such as entering the labour market, birth of a child, and children starting school. The qualitative longitudinal approach used in this thesis to explore mobility and daily travel patterns upon retirement, provides a deeper understanding of how the interaction between individuals, tools, material artefacts and the physical environment create demands for travel and different preconditions for mobility in later life.

\subsection{Time-space constraints for mobility and activity participation}

The analysis shows that the informants experienced different types of time-space constraints for mobility and activity participation. Some of these constraints were consequences of having left paid work, while others were changed in importance upon retirement. Coupling constraints concerned commitments and were found among those who had taken on greater responsibility for older parents, grandchildren and the household, and among those who were engaged in voluntary work. The time that was released after leaving paid work enabled these commitments. Constraints should evidently not necessarily be understood in a negative sense. Most often, coupling restrictions arose from a desire to spend more time with family and friends. Fortuijn (1999) drew a similar conclusion in a study of older women's daily life, namely that constraints created meaning and structure, such as the way meals structure the day. Capacity constraints that were identified in this study relate to the informant's ability to travel and to use various means of transport. Mental and physical health caused the most obvious capability constraints, such as consequences of cardiovascular diseases, osteoarthritis, wornout hips or knees, panic disorder and forgetfulness. Lack of mobility tools, e.g. not having a driving licence or a car in the household, also limited the ability to travel when and where one wanted. Another type of capability constraint concerned motivational factors, and these became quite evident for some when the trips to work ended. Having no motivation to go out was experienced especially by those who did not have any commitments to other people or organised activities outside the home, or those who lived alone. Having two retirees in the household also hindered informants in coming up with things to do on their own. On the other hand, partners could also encourage each other to come up with things to do, and keep each other company when one had an errand. But 
when no external factors motivated activities outside the home (such as paid work), there was a risk of passivity and isolation. Lack of financial resources and relying on others to make errands out-of-town were additional coupling constraints. Different types of authority constraints were identified. Lack of transport alternatives implied that some places could not be reached by those who did not have the opportunity to go by car. Those who could not manage changes of bus routes or excessively long journeys were forced to stay at home or to choose another activity. This problem was especially exemplified by Vivian (paper IV) who stopped going to water gymnastics when her allowance to use the special transport services was withdrawn. If she travelled by the ordinary routes, she had to change from bus to tram, which she found too stressful after having a stroke. An authority constraint to participate in activities concerned age norms and notions of retirement. This was illustrated in the sayings of those who were reluctant to join the pensioners' associations, or participate in those activities because they believed they were too young and had completely different interests than pensioners in general. Some missed organised activities that were directed towards younger pensioners, and were suitable for those born during the 1940s.

The informants had found themselves with resources and strategies to overcome the above-mentioned constraints. Those who were unable to drive themselves had either spouses or acquaintances that could give them a ride if needed, which was a resource for mobility. Walking and cycling was a strategy to maintain good health and mobility and to manage everyday errands and activities. Some used the car more after the ability to walk had declined. A strategy to avoid the risk of being lonely was to acquire new acquaintances by joining associations. This also created new activities and demands for mobility. Perhaps the most important resources for mobility were proximity to shopping and service facilities, and good health in general, although the informants saw it the other way around - that mobility brought and maintained good health.

\subsection{The car remains important}

Much previous research has shown that the car implies freedom and independence (Davey, 2007; Kostyniuk and Shope, 2003; Zeitler and Buys, 2015). This was also found in the present thesis. Although the informants highly valued walking and 
cycling and said that they walked and cycled more than before, the travel diaries showed that the most used mode of transport during the diary week was the car. The car was often used for short trips of about 5-10 minutes one way, and for carrying out single errands. Figure 3 is based on all informants' travel diaries and shows that the car was the most used mode of transport on weekdays and was used in order to carry out many different activities.

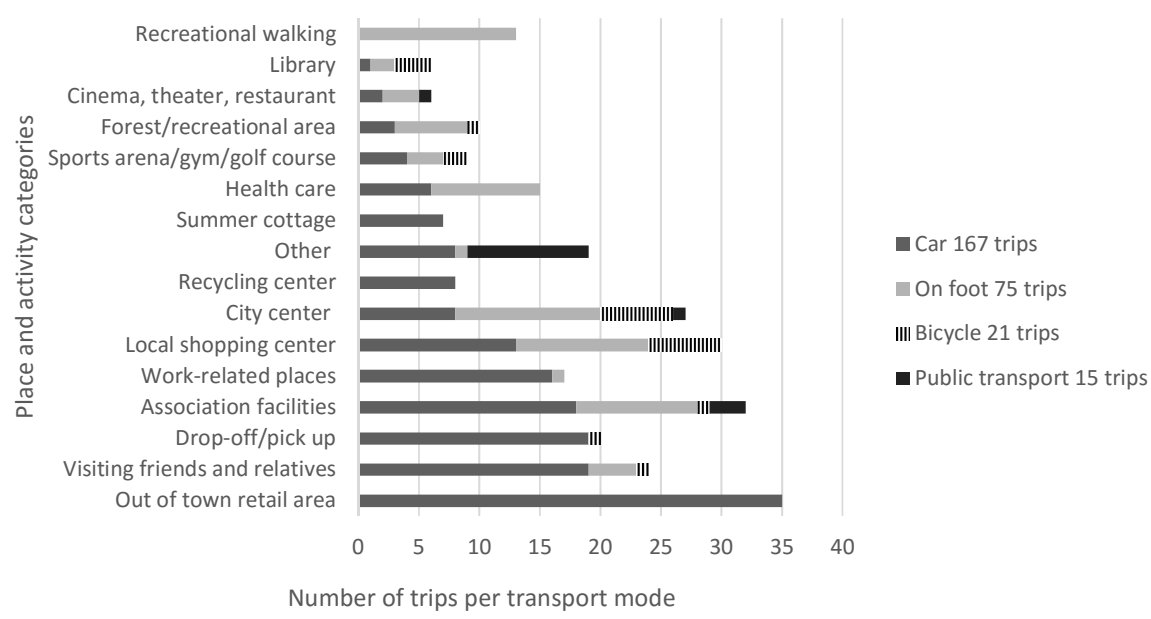

Figure 3 Number of trips per mode of transport to different activities and places outside the home during one week, Monday to Sunday. Based on travel diaries from 24 informants.

The thought of giving up driving had not occurred to those who were still driving at the second interview occasion. They said that some projects in their everyday life would be difficult to carry out without a car: playing golf, excursions to nature reserves, picking up grandchildren, shopping out-of-town and household projects such as renovation. What one informant said exemplified how car use was motivated. He argued that he would not walk ten minutes to the bus stop when it took ten minutes to drive into the city including parking, which was contrary to how most informants reasoned about walking versus driving. Similar arguments have been found in research on how individuals negotiate environmental responsibilities, where people portray environmentally-friendly lifestyles as difficult to implement as the transport system and time restrictions do not allow 
many transport choices apart from the car (Dahl, 2014). The car was as significant as before retirement for the informants in this study who owned one. It still implied freedom to go wherever they wanted and not having to wait for a bus or being dependent on other people. The car was also used for other reasons than before. Because the informants had extended free time, they helped others who needed a ride or assistance. Zeitler and Buys (2015) obtained similar results in a study of mobility among older people in a suburban environment in Australia. Previous research has shown that being able to drive and having a car available in the household allow people to maintain their activities and participate in society, which contribute to healthy and active ageing (Alsnih and Hensher, 2003; WHO, 2012). Older people without driving licences report wanting to make more trips than they are able to (Siren and Hakamies-Blomqvist, 2004). When Erik in this study bought a car a few years after retirement, his mobility increased and he was able to participate again in activities with his old friends, and he was able to give other people rides. These results show that at certain periods in life, and for people with restricted health, the car is especially important in order to manage the everyday activities and responsibilities. However, positive experiences of driving cessation have been found. For example, Inger in this study sold her car because she saw no use for it anymore and she had become uncomfortable with driving. Her husband now drove them in his car, but mostly she walked. Similar mobility strategies have been found elsewhere. People can manage everyday life without a car by planning activities differently, changing destinations, re-evaluating the local environment, and allowing more time for transport (Berg and Levin, 2011; Musselwhite and Shergold, 2013; Oxley et al., 2010). The reasons for reducing driving are important factors affecting how it will be experienced. People who reduce their driving due to a lesser need to drive, for lifestyle reasons, due to discomfort when driving or decreased enjoyment are less negative about driving cessation (Oxley et al., 2010). Furthermore, driving cessation is usually not abrupt, but is a gradual process generated by other needs for mobility, which gives time to acclimatize to a life without a car (Siren and Haustein, 2014). The informants in this study lived in an urban environment within walking distance of shops and services, and an extensive public transport system was available. People living in rural areas where such services are further away and less developed might experience everyday life without a car as more difficult. However, an 
interesting result in the present thesis is how important the car still is in an urban environment with many mobility options.

The results in this thesis align with studies that show that the power of habits is strong when it comes to car use (Bamberg et al., 2003; Carrus et al., 2008). The informants said that they were sometimes lazy or habitually used the car for errands that could be carried out by other means of transport. Previous studies have highlighted that the frequent car use among older people contribute to environmental problems and damage health (Buys et al., 2012; Pillemer et al., 2011). If communities want to reduce car use in favour of more environmentally friendly modes of transport, opportunities to travel without a car and still manage the everyday juggling must be provided. Campaigns targeting people when they experience certain key events or transition points in life might be effective. Free public transport for a certain period of time can encourage newly retired people to try this alternative when they face a new situation in life and they have more time at their own disposal. Public transport might not be used so much while health allows walking longer distances and driving, but just by knowing what service is offered and how the system works can increase its use in the future. The informants occasionally combined walking and public transport, which suggests that there is a potential that public transport can be further used. To have several transport mode options (including public) is insurance against becoming isolated when physical and mental capacities decline as one gets older.

\subsection{Multiple transitions and changes in mobility over time}

A theoretical starting point in this thesis was that adjusting to retirement is a process that takes time and is influenced by various resources. The results show that changes in life after retirement, new or lost social relations, grandparenthood, new social places, partners retirement, illnesses and recoveries, divorces and change of residence, in different ways influence the experience of the first years of retirement and the meaning and preconditions for mobility. For example, a move closer to the city changes the need for a car for daily activities, and increases the amount of walking for transport. One example of changed meaning of mobility was described by Gösta, who after a serious illness was more eager to travel abroad and make use of the time in life that he had left. Eva's case exemplified 
how the experiences of the first year of retirement are influenced when a daughter with a new-born child needed extra support, which also prevented Eva from being away for longer periods. Declined health and loss of energy due to physical ageing implies that walks are shortened, the car is used more, or that the individual has to cease driving and rely on public transport or ride with others. Experiences of an acute illness can cause feelings of anxiety and the individual can become afraid to leave home, worrying that he/she will become ill again, which in this study is exemplified by Erik. These results align with Wang et al. (2011) who suggests that changes in resources influence the process of adjusting to retirement.

Atchley (1976) has described the process of adjusting to retirement as having several phases. The model has received some support in previous studies, which have used quantitative analysis methods (Gall et al., 1997; Pinquart and Schindler, 2007; Reitzes and Mutran, 2004). The qualitative analysis of the interviews in this thesis can discern the different phases of Atchleys' model, but it also modifies and extends the model. For example, an initial phase similar to Atchley's honeymoon phase can be discerned, when the individual is satisfied and enjoys life in general, but is occupied by trying to do carry out all activities that there was no time to do before. Mobility in this phase include shopping trips related to house renovation and other planned projects, and walking and cycling for exercise. Those who believed after retirement, that they had too few activities and would have preferred to continue working, described a period similar to Atchley's disenchantment phase already at the beginning of retirement and still experienced this during the second interview. A mobility strategy that was used in this phase is to go into the city or go on small shopping errands every day to the local shopping centre, to see some people or to pass some time. Some informants said that they felt that they had nothing to travel to and mobility thus became constrained, which is why disenchantment was experienced. According to Atchley, the retiree's life in a stability phase is predictable and satisfying and dealing with physical decline has become part of everyday routines. For example, the interviews with Gösta, Vivian and Erik in this study revealed such as phase. As has been said earlier, physical decline had not made the informants give up on activities that they had always engaged in; rather they had adapted to abilities and these had become part of their routinized everyday life. Atchley (1976) points out that not everybody experiences retirement through different phases, and that some only experience a 
few, and furthermore, that phases can be experienced in a different order. This makes the idea of seeing retirement adjustment through different phases rather weak and the model loses in usefullness. However, Atchley refers to the phases as typical processes of adjustment that occur when the individual is approaching or abandoning a certain role. Similar processes were described by the informants in this thesis. Based on the results of this thesis, an alternative initial phase is suggested, the recovery phase. Several of the informants said that their jobs were very stressful and that they were exhausted when they finally retired. During the recovery phase, the retiree wants to slow down and recover from a high working pace. Finding other activities than work to fill the days is not yet a priority. One might speculate that this phase is more applicable to the generation that was born after the Second World War, since many women have been working full time, compared to previous generations that have retired, and much household related activities thus remains when they come home from work. If and when the retiree has recovered, a phase similar to Atchley's honeymoon phase might begin. 


\section{Conclusion}

This thesis shows that retirement is a period when new mobility strategies and travel activities are considered, evaluated and practised. For the informants in this study, the extended free time that became available upon retirement was used for new activities and/or spending more time on activities they always have had, such as caring for grandchildren and old parents, volunteer work, and household projects, and more time was spent on activities they already engaged in. For some, it was difficult to find things to do to pass the time. Having more time at one's own disposal meant that they could walk or cycle to a greater extent than when they still worked, which they highly valued. Despite these arguments, the significance of the car had not decreased. Rather, the car was the most used mode of transport for many, according to the travel diaries. As expressed by the informants, mobility had become a means to form a daily structure, to get exercise and maintain good health. However, retirement also implies the opportunity to remain at home all day. The needs and preconditions for mobility and activity participation upon retirement depend on a range of circumstances; individual preferences, habits, other people's needs and time schedules, other people's support, the geographical locations where activities take place, and the individual ability and preconditions given in order to overcome distances. Four dimensions of mobility can be discerned from the perspective of newly retired people: In the first dimension (1), mobility is understood as a means of carrying out activities which are needed and desired. This dimension is in accordance with an activitybased perspective on travel demands (Rasouli and Timmermans, 2014). Activities and commitments create demands for mobility, and newly retired people do not differ in this respect from other groups in society. In the second dimension (2), mobility is a resource for creating activities. People find that being active is beneficial for maintaining health. However, some lack the motivation to get out of the house, and some feel that they have nothing to travel to, which is why activities are created. This dimension of mobility becomes especially apparent when the journeys to and from work end upon retirement. The third dimension (3) concerns mobility as a leisure activity in itself and has previously been outlined for example by Cao et al. (2009) and Mokhtarian et al. (2015), and is also referred to as intrinsic travel. The results of this study show that walking and cycling are often used for this type of mobility and often to combine errands and exercising. 
These three dimensions represent mobility as an activity that is desirable and has certain benefits for individuals. The results of this study also reveal a fourth dimension (4), mobility as subordinate to staying at home. During working life, this option is limited due to temporal and spatial boundaries to paid work; rather, the free time has to be utilized in every way possible. Having the opportunity to remain at home becomes a treat upon retirement. This dimension partly results from the fact that the retiree has left a stressful working life and needs to rest and recover.

\subsection{Further research}

The thesis raises a number of questions that should be considered in future research. First, the methods used, a combination of travel diaries and qualitative interviews, should be further developed not only in research on older people, but in research on mobility biographies. The method is useful for producing knowledge of the complexities in people's everyday lives, within different types of households that demand mobility in different ways and for different reasons. A combination of several methods - interviews, travel diaries, traditional travel surveys and stated preference studies - complement each other and can provide deeper knowledge of how mobility needs are generated, how choices of modes of transport are made, and of opportunities to make changes in travel mode choices in different geographical and social settings. Studying several persons' activities and trips at one time, such as people within the same household, can provide increased understanding of the coupling constraints that many households struggle with every day. Today, there are few such qualitative studies and the possibility of modelling several individuals is also lacking in aggregated quantitative models.

Second, to have older people write travel diaries provided in this study important knowledge of the informant's actual trips undertaken and the constraints they faced in order to maintain their desired mobility. Similar knowledge is lacking today in mobility research concerning older people since there are few qualitative studies. The Swedish national travel survey does not include persons who are older than 84 years, nor does this present thesis. 
Third, to continue to study the informants who participated in this study would be essential in order to understand how people adapt to further changes in later life and how mobility develops as people become older and presumably frailer. How do the informants adjust to retirement and ageing as time goes by? And what significance does mobility have in this adjustment? To what extent can a longitudinal study of ageing among people born during the 1940s develop new knowledge of different phases in later life and processes of aging? Research on this topic can be a valuable contribution to life-course research.

Fourth, further research on the connection between environmentally sustainable travel and ageing is needed. What incentives work to promote walking and cycling and reduce car use among older people without running the risk of reducing their mobility? Research questions within this area would benefit from a collaboration between housing researchers and transport researchers as well as with policymakers and planners.

Finally, studying older people's mobility by considering local geographical aspects is important in order to understand how time-space use is affected when mobility declines as a consequence of physical and mental ageing. To what extent and in what ways can older people continue to participate in activities and maintain social networks even though their potential spatial reach is reduced? Although urban environments in general offer several transport mode options and proximity to shops and services, it needs to be considered how different areas within the same city create different preconditions for mobility, activity participation and sustainable transport among older people. Studies similar to the present thesis need to be conducted in other middle-sized cities as well as in smaller and larger cities and rural areas. Furthermore, comparison with other countries, in Europe and internationally, would be fruitful in order to understand how social, cultural and geographical contexts influence mobility and travel activities in later life. Studies within this area would also have to take into account gender aspects and generational differences with the intention of highlighting heterogeneity among older people. The knowledge that such research provide can be an asset for transport- and public health policy and planning. 


\section{$8 \quad$ Summary in Swedish}

\section{Vardagsmobilitet och resande under de första åren som pensionär}

I avhandlingen studeras mobilitet och resande hos nyblivna pensionärer. Mobilitet är centralt för oberoende och för att kunna vara delaktig i samhället och uppleva välbefinnande när man åldras. Vid särskilda händelser eller övergångsfaser i livet när förändringar i vardagsstrukturen sker kan även behovet av mobilitet och val av transportmedel förändras. Pensioneringen är en sådan händelse i livet som innebär förändringar $\mathrm{i}$ den tidsrumsliga ${ }^{5}$ användningen och förändrade vardagsrutiner: resan till och från arbetet försvinner, nya sociala mönster formas och individen får mer tid till sitt eget förfogande. Det övergripande syftet med avhandlingen är att utforska mobilitetsstrategier och förändringar i mobilitet vid pensioneringen och hur mobiliteten utvecklas under de första åren som pensionär. Ytterligare ett syfte är att få ökad kunskap om i vilken utsträckning människor kan upprätthålla en önskad mobilitet utifrån deras egna behov och förutsättningar när de går i pension. I anslutning till syftet ställs ett antal forskningsfrågor som besvaras i fyra forskningsartiklar: Vilka aktiviteter utanför hemmet deltar nyblivna pensionärer i och var sker dessa aktiviteter? I vilken utsträckning och av vilka anledningar förändras aktiviteter när man går i pension? (Artikel I). Vilka resurser och begränsningar påverkar nyblivna pensionärers förmåga att resa när, var och hur de vill? Vad betyder mobilitet för nyblivna pensionärer och hur kommer deras erfarenheter av mobilitet i uttryck? (Artikel II). I vilken utsträckning används bilen för vardagsmobiliteten i denna fas i livet och hur värderas bilen jämfört med andra transportmedel? (Artikel III). Hur utvecklas mobilitetsstrategier under de första åren som pensionär? (Artikel IV). Studien har särskilt genomsyrats av det tidsgeografiska perspektivet, vilket belyser människors användning av tid, plats och resurser i genomförandet av aktiviteter,

${ }^{5}$ Begreppet tidrum förklarar hur tid och överbryggandet av rum interagerar och utgör både en resurs och en restriktion för människors handlingar (Hägerstrand, 1970a). 
de sammanhang vari aktiviteterna sker samt begränsningar som påverkar möjligheterna att genomföra aktiviteter.

För att besvara syftet har en kvalitativ metod med två datainsamlingsmetoder använts: resdagböcker och kvalitativa intervjuer. Resdagböcker förväntades ge svar på hur och var människor reser medan kvalitativa intervjuer förväntades ge svar på betydelsen av och erfarenheter av mobilitet, samt vilka resurser och begränsningar som har betydelse för att människor ska kunna resa när, var och hur de vill. Intervjuer genomfördes i oktober 2011 med 24 personer som inte hade varit pensionärer i mer än ett år. I mars 2015 intervjuades samma personer igen för att ta reda på om och i så fall hur mobiliteten förändras efter tid. Tre av dessa intervjuer genomfördes med två personer i hushållet ifall det var så att den tidigare intervjuades partner hade gått i pension sedan den första intervjun. Totalt intervjuades 27 personer. Samtliga bodde i Norrköping, vilket valdes för att begränsa studieområdet och som representant av en medelstor svensk stad. Analysen av intervjuerna genomfördes med hjälp av kvalitativ innehållsanalys. Som ett praktiskt hjälpmedel vid analysen användes MAXQDA 10, ett mjukvaruprogram för kvalitativ analys. Resdagböckerna analyserades med hjälp av VISUAL- TimePAcTS, en applikation för att kunna visualisera och utforska dagboksdata.

Avhandlingens resultat visade att den utökade tiden som pensioneringen gav innebar vissa förändringar i resandet och att betydelsen av mobilitet förändrades. Eftersom många inte längre har bråttom kunde de promenera och cykla till aktiviteter och platser dit de tidigare körde bil. Mobiliteten hade blivit ett sätt att skapa en struktur i vardagen som liknade den struktur de hade när de fortfarande förvärvsarbetade. Ärenden och andra aktiviteter kombinerades med fysisk aktivitet vilket innebar att omvägar till den lokala matbutiken togs för att ärendet skulle bli en motionsrunda. Att vara fysiskt och mentalt aktiv var ett sätt att hålla ohälsan och åldrandet ifrån sig. Mobilitet var ofta önskvärt och förknippades med positiva känslor, men några behövde tvinga sig själva att gå ut och skapade därför ärenden. Att stanna hemma en hel dag förekom också, vilket några menade att de unnade sig efter att ha lämnat ett stressigt yrkesliv bakom sig. Trots utsagor om vikten av att hålla sig fysiskt aktiv och att man gärna gick och cyklade användes bilen i mycket hög utsträckning till de flesta aktiviteter, enligt resdagböckerna. 
Informanterna menade att de använde bilen av gammal vana eller för att de var lata, och att många ärenden istället skulle kunna ha genomförts till fots. Bilen var viktig för att kunna genomföra vardagens olika projekt och aktiviteter såsom renovering, spela golf och veckohandla, men också för att underlätta för barnen och barnbarnen att få vardagspusslet att gå ihop och för att skjutsa vänner som inte hade möjlighet att köra själva.

Nya tidsrumliga begräsningar för mobilitet och deltagande i aktiviteter uppstod $\mathrm{i}$ vardagen som pensionär; åtaganden gentemot barn och gamla föräldrar, arbete i frivilligorganisationer, nedsatt hälsa, minskad motivation till att gå ut och begränsade resurser att kunna resa med bil, buss eller att gå längre sträckor. För de som inte hade möjlighet att resa med bil eller inte klarade av att byta buss eller resa långt med kollektivtrafiken blev vissa platser onåbara och således blev vissa aktiviteter omöjliga att genomföra. Ytterligare en begränsning för deltagande var att de människor som deltar i vissa aktiviteter upplevdes för gamla och att aktiviteter som var riktade till personer $i$ ens egen ålder saknades. Ett viktigt resultat är att informanterna framförallt hade resurser och strategier för att övervinna de ovan nämnda begränsningarna, såsom god hälsa, sociala nätverk och närhet till handel och service.

Resultatet visade också att olika förändringar som har skett i livet efter pensioneringen hade betydelse för hur den första tiden som pensionär upplevdes och påverkade också betydelsen av mobilitet och förutsättningar att kunna resa: att få barnbarn, att partnern går i pension, nya och förlorade sociala relationer, nya sociala platser, sjukdomar, rehabilitering, skilsmässa och byte av bostad. Informanterna anpassade sig till pensioneringen på olika sätt. Vissa upplevde en s.k. smekmånadsfas i början av pensioneringen då de generellt kände sig tillfreds och njöt av livet, samtidigt som de var fullt upptagna med att försöka hinna med sådant som det inte fanns tid till när de fortfarande arbetade. I denna fas bestod mobiliteten av ärenden relaterade till renoveringsprojekt och andra planerade projekt, samt att gå och cykla för att få motion. De som upplevde att de hade för få aktiviteter efter pensioneringen och hellre skulle ha velat fortsätta att arbeta beskrev en period av besvikelse med pensioneringen, både under första och andra intervjuomgången. En mobilitetsstrategi i denna fas var att gå in på stan och göra småärenden i den lokala butiken för att se folk och få tiden att gå. Men försämrad 
hälsa bidrog inte till att informanterna slutade med aktiviteter som de alltid hade haft utan anpassade sig till den egna förmågan som en del av de dagliga rutinerna. Flera av informanterna beskrev att deras arbete innan pensioneringen var mycket stressigt och att de var utmattade när de gick i pension. I början genomgick de därför en återhämtningsfas där de varvade ner och återhämtade sig från det höga arbetstempot. Under denna fas prioriterades inte engagemang i nya aktiviteter. Slutligen visar avhandlingen på fyra dimensioner av mobilitet i början av pensioneringen: (1) mobilitet är ett medel för att genomföra aktiviteter, (2) mobilitet är en resurs för att skapa aktiviteter, (3) mobiliteten är en önskvärd aktivitet i sig, samt att (4) mobilitet är underordnat betydelsen av att kunna stanna hemma. 


\section{$9 \quad$ References}

Adams, G.A. and Rau, B.L. (2011) Putting off tomorrow to do what you want today: planning for retirement. American Psychologist 66: 180-192.

Alsnih, R. and Hensher, D.A. (2003) The mobility and accessibility expectations of seniors in an aging population. Transportation Research Part A-Policy and Practice 37: 903-916.

Andersson, B. (2001) Rädslans rum: trygghetens rum - ett forskningsprojekt om kvinnors vistelse $i$ trafikrummet. Vinnova Rapport VR 2001:32: Stockholm.

Andersson, L. and Öberg, P. (2006) Diversity, health and ageing. In: Daatland S.O. and Biggs S. (eds) Ageing and diversity. Multiple pathways and cultural migration. Bristol: Policy Press, 45-60.

Atchley, R.C. (1976) The sociology of retirement. New York: Wiley.

Atchley, R.C. (1999) Continuity theory, self, and social structure. In: Ryff C.D. and Marshall V.W. (eds) Self and Society in Aging Processes. New York, NY: Springer Publishing Company, 145-158.

Bamberg, S., Ajzen, I. and Schmidt, P. (2003) Choice of travel mode in the theory of planned behavior: the roles of past behavior, habit, and reasoned action. Basic and Applied Social Psychology 25: 175-187.

Bamberg, S., Fujii, S., Friman, M., et al. (2011) Behaviour theory and soft transport policy measures. Transport Policy 18: 228-235.

Barnes, H. and Parry, J. (2004) Renegotiating identity and relationships: men and women's adjustments to retirement. Ageing and Society 24: 213-233.

Beige, S. and Axhausen, K.W. (2012) Interdependencies between turning points in life and long-term mobility decisions. Transportation 39: 857-872. 
Berg, J. and Levin, L. (2011) Äldres vardagliga resor: val av färdmedel och erfarenheter av kollektivtrafik. VTI rapport 734. Linköping: Statens Vägoch Transportforskningsinstitut.

BILSweden. (2014) Körkortsstatistik. Andel med körkort december 2014. URL: http://www.bilsweden.se/statistik/korkort. (Accessed 24.01.2016).

Bowling, A., Gabriel, Z., Dykes, J., et al. (2003) Let's ask them: a national survey of definitions of quality of life and its enhancement among people aged 65 and over. International Journal of Aging \& Human Development 56: 269306.

Burkhardt, J. (1999) Mobility changes: their nature, effects, and meaning for elders who reduce or cease driving. Transportation Research Record: Journal of the Transportation Research Board 1671: 11-18.

Buys, L., Snow, S., van Megen, K., et al. (2012) Transportation behaviours of older adults: an investigation into car dependency in urban Australia. Australasian Journal on Ageing 31: 181-186.

Cao, X.Y., Mokhtarian, P.L. and Handy, S.L. (2009) No particular place to go: an empirical analysis of travel for the sake of travel. Environment and Behavior 41: 233-257.

Carrus, G., Passafaro, P. and Bonnes, M. (2008) Emotions, habits and rational choices in ecological behaviours: the case of recycling and use of public transportation. Journal of Environmental Psychology 28: 51-62.

Centrum för konsumtionsvetenskap. (2009) Konsumtionsrapporten 2009. Göteborg: Centrum för konsumtionsvetenskap, Handelshögskolan vid Göteborgs universitet.

Chaudhury, H., Mahmood, A., Michael, Y.L., et al. (2012) The influence of neighborhood residential density, physical and social environments on older adults' physical activity: an exploratory study in two metropolitan areas. Journal of Aging Studies 26: 35-43. 
Cools, M., Moons, E., Janssens, B., et al. (2009) Shifting towards environmentfriendly modes: profiling travelers using Q-methodology. Transportation 36: 437-453.

Coughlin, J.F. (2009) Longevity, lifestyle, and anticipating the new demands of aging on the transportation system. Public Works Management \& Policy 13: 301-311.

Crawford, R. (2006) Health as a meaningful social practice. Health 10: 401-420.

Cresswell, T. (2006) On the move: mobility in the modern western world. New York: Routledge.

Cresswell, T. (2010) Towards a politics of mobility. Environment and Planning D: Society and Space 28: 17-31.

Currie, G. and Delbosc, A. (2010) Exploring public transport usage trends in an ageing population. Transportation 37: 151-164.

Dahl, E. (2014) Om miljöproblemen hänger på mig: individer förhandlar sitt ansvar för miljön. Doctoral Dissertation. Institutionen för Tema- Tema teknik och social förändring, Linköpings universitet. Göteborg: Makadam.

Davey, J.A. (2007) Older people and transport: coping without a car. Ageing \& Society 27: 49-65.

Day, R. (2008) Local environments and older people's health: dimensions from a comparative qualitative study in Scotland. Health \& Place 14: 299-312.

Dukic, T. and Broberg, T. (2012) Older drivers' visual search behaviour at intersections. Transportation Research Part F - Traffic Psychology and Behaviour 15: 462-470.

Elder, G.H. (1994) Time, human agency and social change - Perspectives on the life course. Social Psychology Quarterly 57: 4-15. 
Ellder, E. (2014) Residential location and daily travel distances: the influence of trip purpose. Journal of Transport Geography 34: 121-130.

Ellegård, K. (1998) Under ytan - ingångar till det kulturgeografiska äventyret. In: Gren M. and Hallin P.-O. (eds) Svensk kulturgeografi: en exkursion inför 2000-talet. Lund: Studentlitteratur, 86-116.

Ellegård, K. (1999) A time-geographical approach to the study of everyday life of individuals - a challenge of complexity. GeoJournal 48: 167-175.

Ellegård, K., Nordell, K. and Westermark, Å. (1999) Att ta kontroll över sitt vardagsliv: kvalitativ dagboksmetod för reflektiv emancipation. In: Lindén J., Westlander G. and Karlsson G. (eds) Kvalitativa metoder $i$ arbetslivsforskning. Stockholm: Rådet för arbetslivsforskning, 108-131.

Ellegård, K. and Svedin, U. (2012) Torsten Hägerstrand's time-geography as the cradle of the activity approach in transport geography. Journal of Transport Geography 23: 17-25.

Eurostat. (2011) Persons with low educational attainment, by age group. URL: http://epp.eurostat.ec.europa.eu/portal/page/portal/education/data/main_ta bles. (Accessed 21.11.2013).

Fingerman, K.L., Pillemer, K.A., Silverstein, M., et al. (2012) The baby boomers' intergenerational relationships. Gerontologist 52: 199-209.

Flyvbjerg, B. (2006) Five misunderstandings about case-study research. Qualitative Inquiry 12: 219-245.

Fortuijn, J.D. (1999) Daily life of elderly women in a rural area in The Netherlands. GeoJournal 48: 187-193.

Fortuijn, J.D., van der Meer, M., Burholt, V., et al. (2006) The activity patterns of older adults: a cross-sectional study in six European countries. Population, Space and Place 12: 353-369. 
Friberg, T. (2003) Prismans lyskraft och feministiska tolkningar. In: Clark E., Hallin P. and Widegren M. (eds) Tidsrumsfragment. Rapporter och notiser $n r$ 165. Lunds universitet: Institutionen för kulturgeografi och ekonomisk geografi.

Frändberg, L. and Vilhelmson, B. (2011) More or less travel: personal mobility trends in the Swedish population focusing gender and cohort. Journal of Transport Geography 19: 1235-1244.

Gall, T.L., Evans, D.R. and Howard, J. (1997) The retirement adjustment process: changes in the well-being of male retirees across time. Journals of Gerontology Series B-Psychological Sciences and Social Sciences 52: 110117.

Giddens, A. (1984) The constitution of society: outline of the theory of structuration. Cambridge: Polity Press.

Gilleard, C. and Higgs, P. (2000) Cultures of ageing: self, citizen and the body. Harlow: Prentice Hall.

Gilleard, C. and Higgs, P. (2002) Concept Forum - The third age: class, cohort or generation? Ageing \& Society 22: 369-382.

Gilleard, C. and Higgs, P. (2007) The third age and the baby boomers. International Journal of Ageing and Later Life 2: 13-30.

Godfrey, M., Townsend, J. and Denby, T. (2004) Building a good life for older people in local communities: the experience of ageing in time and place. York: Joseph Rowntree Foundation.

Graneheim, U.H. and Lundman, B. (2004) Qualitative content analysis in nursing research: concepts, procedures and measures to achieve trustworthiness. Nurse Education Today 24: 105-112.

Grenier, A. (2011) Transitions and the lifecourse: challenging the constructions of 'growing old'. Bristol: Policy Press. 
Hagberg, J.-E. (2008) Livet genom tekniklandskapet: livslopp, åldrande och vardagsteknikens förändring. Norrköping: Nationella Institutet för Forskning om Äldre och Åldrande (NISAL), Linköpings universitet.

Hallgrimsdottir, B., Svensson, H. and Ståhl, A. (2015) Long term effects of an intervention in the outdoor environment - a comparison of older people's perception in two residential areas, in one of which accessibility improvements were introduced. Journal of Transport Geography 42: 9097.

Haustein, S. (2012) Mobility behavior of the elderly: an attitude-based segmentation approach for a heterogeneous target group. Transportation 39: 1079-1103.

Haustein, S. and Siren, A. (2015) Older people's mobility: segments, factors, trends. Transport Reviews 35: 466-487.

Hay, M., Gabaude, C., Stave, C., et al. (2013) Training needs analysis - Towards a training curriculum, Safe Move for Older Drivers Report. Delivarable n'2.1.3. URL: http://www.chalmers.se/safer/EN/publications/precrash/2014/training-needs-analysis. (Accessed 25.01.2016).

Heikkinen, S. (2008) Att köra eller inte köra: hur de äldre, åldrande och bilkörning har diskuterats i svensk transportpolitik. Doctoral Dissertation. Sociologiska Institutionen, Uppsala: Uppsala universitet.

Hjorthol, R. (2013) Transport resources, mobility and unmet transport needs in old age. Ageing \& Society 33: 1190-1211.

Hjorthol, R.J., Levin, L. and Siren, A. (2010) Mobility in different generations of older persons: the development of daily travel in different cohorts in Denmark, Norway and Sweden. Journal of Transport Geography 18: 624633.

Hsieh, H.F. and Shannon, S.E. (2005) Three approaches to qualitative content analysis. Qualitative Health Research 15: 1277-1288. 
Hägerstrand, T. (1970a) Tidsanvändning och omgivningsstruktur. In: SOU 1970:14 (ed) Urbaniseringen i Sverige: en geografisk samhällsanalys Stockholm, Bilaga 4.

Hägerstrand, T. (1970b) What about people in Regional Science? Papers in Regional Science 24: 6.

Hägerstrand, T., Carlestam, G. and Sollbe, B. (1991) Om tidens vidd och tingens ordning: texter av Torsten Hägerstrand. Stockholm: Statens råd för byggnadsforskning.

Hägerstrand, T. and Lenntorp, B. (1974) Samhällsorganisation i tidsgeografiskt perspektiv. In SOU 1974: 2 (ed) Ortsbundna levnadsvillkor. Stockholm, Bilaga 2.

Hörschelmann, K. (2011) Theorising life transitions: geographical perspectives. Area: $378-383$.

Jacques, C., Manaugh, K. and El-Geneidy, A.M. (2013) Rescuing the captive mode user: an alternative approach to transport market segmentation. Transportation 40: 625-645.

Jonsson, H. (2011) The first steps into the third age: the retirement process from a Swedish perspective. Occupational Therapy International 18: 32-38.

Jonsson, H., Borell, L. and Sadlo, G. (2000) Retirement: an occupational transition with consequences for temporality, balance and meaning of occupations. Journal of Occupational Science 7: 29-37.

Katz, S. (2000) Busy bodies: activity, aging, and the management of everyday life. Journal of Aging Studies 14: 135-152.

Kjellman, C. (2003) Ta plats eller få plats? Studier av marginaliserade människors förändrade vardagsliv. Doctoral Dissertation. Institutionen för kulturgeografi och ekonomisk geografi, Lund: Lunds Universitet. 
Kostyniuk, L.P. and Shope, J.T. (2003) Driving and alternatives: older drivers in Michigan. Journal of Safety Research 34: 407-414.

Krekula, C. and Heikkinen, S. (2011) Det heterogena åldrandet: Vad kan begreppet tredje åldern tillföra? In: Gynnerstedt K. and Wolmesjö M. (eds) Tredje åldern: Sociala aspekter och medborgarskap. Malmö: Gleerups, 4962.

Krogstad, J.R., Hjorthol, R. and Tennøy, A. (2015) Improving walking conditions for older adults. A three-step method investigation. European Journal of Ageing 12: 249-260.

Kvale, S., Brinkmann, S. and Torhell, S.-E. (2009) Den kvalitativa forskningsintervjun. Lund: Studentlitteratur.

Kwan, M.P. (2000) Gender differences in space-time constraints. Area 32: 145156.

Lanzendorf, M. (2003) Mobility biographies. A new perspective for understanding travel behaviour. Paper presented at the 10th International Conference on Travel Behaviour Research: Moving through nets: The physical and social dimensions of travel. Lucerne, 10th-15th August 2003.

Larsson, S. (2009) A pluralist view of generalization in qualitative research. International Journal of Research \& Method in Education 32: 25-38.

Laslett, P. (1991) A fresh map of life: the emergence of the Third Age. Cambridge, Mass.: Harvard U.P.

Liddle, J., Gustafsson, L., Bartlett, H., et al. (2012) Time use, role participation and life satisfaction of older people: impact of driving status. Australian Occupational Therapy Journal 59: 384-392.

Lindgren, M. (2005) Rekordgenerationen: vad de vill och hur de tänker. Stockholm: Bookhouse Publishing. 
Lundin, P. (2008) Bilsamhället: ideologi, expertis och regelskapande $i$ efterkrigstidens Sverige. Doctoral Dissertation. Skolan för arkitektur och samhällsbyggnad (ABE). Filosofi och teknikhistoria, Stockholms universitet, Stockholm: Monografier utgivna av Stockholms stad, 02825899 ; 193, Stockholmia förlag.

Macnicol, J. (2015) Neoliberalising old age. Cambridge: Cambridge University Press.

Majanen, P., Mellberg, L., Norén, D., et al. (2007) Äldrelivsbranschen: en framtidsbransch. Stockholm: KK-stiftelsen.

Massey, D. (1991) A global sense of place. In: Daniels S. and Lee R. (eds) Exploring human geography. London: Arnold, 237-245.

McQuoid, J. and Dijst, M. (2012) Bringing emotions to time geography: the case of mobilities of poverty. Journal of Transport Geography 23: 26-34.

Metz, D.H. (2000) Mobility of older people and their quality of life. Transport Policy 7: 149-152.

Miranda-Moreno, L.F. and Lee-Gosselin, M. (2008) A week in the life of baby boomers: how do they see the spatial-temporal organization of their activities and travel? Transportation 35: 629-653.

Mokhtarian, P.L., Salomon, I. and Singer, M.E. (2015) What moves us? An interdisciplinary exploration of reasons for traveling. Transport Reviews 35: 250-274.

Mollenkopf, H., Baas, S., Marcellini, F., et al. (2005) Mobility and the quality of life. In: Mollenkopf H., Marcellini F., Ruoppila I., et al. (eds) Enhancing mobility in later life: personal coping, environmental resources and technical support; the out-of-home mobility of older adults in urban and rural regions of five European countries. Amsterdam: IOS Press, 279-288. 
Mollenkopf, H., Marcellini, F., Ruoppila, I., et al. (2004) Social and behavioural science perspectives on out-of-home mobility in later life: findings from the European project MOBILATE. European Journal of Ageing 1: 45-53.

Muratore, A.M., Earl, J.K. and Collins, C.G. (2014) Understanding heterogeneity in adaptation to retirement: a growth mixture modeling approach. International Journal of Aging \& Human Development 79: 131-156.

Musselwhite, C.B.A. and Shergold, I. (2013) Examining the process of driving cessation in later life. European Journal of Ageing 10: 89-100.

Müggenburg, H., Busch-Geertsema, A. and Lanzendorf, M. (2015) Mobility biographies: a review of achievements and challenges of the mobility biographies approach and a framework for further research. Journal of Transport Geography 46: 151-163.

Neutens, T., Delafontaine, M., Scott, D.M., et al. (2012) An analysis of day-today variations in individual space-time accessibility. Journal of Transport Geography 23: 81-91.

Nordbakke, S. (2013) Capabilities for mobility among urban older women: barriers, strategies and options. Journal of Transport Geography 26: 166174.

Nyberg, J., Peters, B. and Levin, L. (2009) Vidareutbildning för äldre bilförare: en översikt. VTI notat, 12-2009. Linköping: Statens väg- och transportforskningsinstitut.

Oakil, A.M., Ettema, D., Arentze, T., et al. (2014) Changing household car ownership level and life cycle events: an action in anticipation or an action on occurrence. Transportation 41: 889-904.

Oldenburg, R. (1999) The great good place: cafés, coffee shops, bookstores, bars, hair salons, and other hangouts at the heart of a community. New York: Marlowe. 
Owsley, C., Stalvey, B.T., Wells, J., et al. (2001) Visual risk factors for crash involvement in older drivers with cataract. Archives of Ophthalmology 119: 881-887.

Oxley, J., Chariton, J., Scully, J., et al. (2010) Older female drivers: an emerging transport safety and mobility issue in Australia. Accident Analysis and Prevention 42: 515-522.

Oxley, J. and Whelan, M. (2008) It cannot be all about safety: the benefits of prolonged mobility. Traffic Injury Prevention 9: 367-378.

Pensionsmyndigheten. (2014) Antal pensioner och pensionstagare med ålderspension/ äldreförsörjningsstöd i december 2014. URL: https://secure.pensionsmyndigheten.se/23011.html.

(Accessed 24.01.2016).

Pensionsmyndigheten. (2015a) Medelpensioneringsålder och utträdesålder 2014. Stockholm: Pensionsmyndigheten.

Pensionsmyndigheten. (2015b) Orange Rapport - Pensionssystemets årsredovisning 2014. Stockholm: Pensionsmyndigheten.

Pillemer, K., Wells, N.M., Wagenet, L.P., et al. (2011) Environmental sustainability in an aging society: a research agenda. Journal of Aging and Health 23: 433-453.

Pinquart, M. and Schindler, I. (2007) Changes of life satisfaction in the transition to retirement: A latent-class approach. Psychology and Aging 22: 442-455.

Prillwitz, J., Harms, S. and Lanzendorf, M. (2006) Impact of life-course events on car ownership. Transportation Research Record: Journal of the Transportation Research Board 1985: 71-77.

Prillwitz, J., Harms, S. and Lanzendorf, M. (2007) Interactions between residential relocations, life course events, and daily commute distances. Transportation Research Record: Journal of the Transportation Research Board 2021: 64-69. 
Rantakokko, M., Manty, M., Iwarsson, S., et al. (2009) Fear of moving outdoors and development of outdoor walking difficulty in older people. Journal of the American Geriatrics Society 57: 634-640.

Rasouli, S. and Timmermans, H. (2014) Activity-based models of travel demand: promises, progress and prospects. International Journal of Urban Sciences 18: 31-60.

Regeringens proposition 2008/09:93. Mål för framtidens resor och transporter. URL:http://data.riksdagen.se/fil/D139D0E8-6831-4E2E-8453F6CAB53D86B4. (Accessed 16.12.2013).

Reitzes, D.C. and Mutran, E.J. (2004) Transition to retirement: stages and factors that influence retirement adjustment. International Journal of Aging \& Human Development 59: 63-84.

Riley, M.W. (1998) A life course approach: autobiographical notes. In: Giele J.Z. and Elder G.H. (eds) Methods of life course research. Qualitative and quantitative approaches. Thousand Oaks: Sage Publications, Inc.,28-51.

Risser, R., Haindl, G. and Ståhl, A. (2010) Barriers to senior citizens' outdoor mobility in Europe. European Journal of Ageing 7: 69-80.

Rose, G. (1993) Feminism and geography: the limits of geographical knowledge. Cambridge: Polity Press.

Saldaña, J. (2003) Longitudinal qualitative research: analyzing change through time. Walnut Creek, Calif.: AltaMira Press.

Sallis, J.F., Frank, L.D., Saelens, B.E., et al. (2004) Active transportation and physical activity: opportunities for collaboration on transportation and public opportunities health research. Transportation Research Part APolicy and Practice 38: 249-268.

Scheiman, S., Moghaddas, H.S., Bjornstig, U., et al. (2010) Bicycle injury events among older adults in Northern Sweden: a 10-year population based study. Accident Analysis and Prevention 42: 758-763. 
Scheiner, J. (2007) Mobility Biographies: elements of a biographical theory of travel demand (Mobilitätsbiographien: bausteine zu einer biographischen theorie der verkehrsnachfrage). Erdkunde 61: 161-173.

Scheiner, J. and Holz-Rau, C. (2013) A comprehensive study of life course, cohort, and period effects on changes in travel mode use. Transportation Research Part A-Policy and Practice 47: 167-181.

Schoenduwe, R., Mueller, M.G., Peters, A., et al. (2015) Analysing mobility biographies with the life course calendar: a retrospective survey methodology for longitudinal data collection. Journal of Transport Geography 42: 98-109.

Scholten, C., Friberg, T. and Sandén, A. (2012) Re-reading time-geography from a gender perspective: examples from gendered mobility. Tijdschrift Voor Economische En Sociale Geografie 103: 584-600.

Schwanen, T., Banister, D. and Anable, J. (2012a) Rethinking habits and their role in behaviour change: the case of low-carbon mobility. Journal of Transport Geography 24: 522-532.

Schwanen, T., Banister, D. and Bowling, A. (2012b) Independence and mobility in later life. Geoforum 43: 1313-1322.

Schwanen, T. and de Jong, T. (2008) Exploring the juggling of responsibilities with space-time accessibility analysis. Urban Geography 29: 556-580.

Schwanen, T., Kwan, M.P. and Ren, F. (2008) How fixed is fixed? Gendered rigidity of space-time constraints and geographies of everyday activities. Geoforum 39: 2109-2121.

Schwanen, T. and Ziegler, F. (2011) Wellbeing, independence and mobility: an introduction. Ageing \& Society 31: 719-733.

Sernhede, O. (2008) Ungdomskulturer som sökande rörelser i det moderna. In: Ellvin M. and Holmbom, L. (eds) Ungdomskulturer - äger eller suger? 
Möjliga möten inom svenskämnet. Stockholm: Svensklärarföreningen. Natur och Kultur, 9-26.

Sheller, M. and Urry, J. (2006) The new mobilities paradigm. Environment and Planning A 38: 207-226.

Siren, A. and Hakamies-Blomqvist, L. (2004) Private car as the grand equaliser? Demographic factors and mobility in Finnish men and women aged 65+. Transportation Research Part F - Traffic Psychology and Behaviour 7: 107-118.

Siren, A. and Hakamies-Blomqvist, L. (2005) Sense and sensibility. A narrative study of older women's car driving. Transportation Research Part FTraffic Psychology and Behaviour 8: 213-228.

Siren, A. and Hakamies-Blomqvist, L. (2009) Mobility and Well-being in Old Age. Topics in Geriatric Rehabilitation 25: 3-11.

Siren, A. and Haustein, S. (2013) Baby boomers' mobility patterns and preferences: what are the implications for future transport? Transport Policy 29: 136-144.

Siren, A. and Haustein, S. (2014) What are the impacts of giving up the driving licence? Ageing \& Society 35: 1821-1838.

Siren, A. and Meng, A. (2013) Older drivers' self-assessed driving skills, drivingrelated stress and self-regulation in traffic. Transportation Research Part F-Traffic Psychology and Behaviour 17: 88-97.

SOU 2010:85. Vem arbetar efter 65 års ålder? En statistisk analys. Stockholm: Socialdepartementet.

Statistics Sweden. (1999) Befolkningsutvecklingen under 250 år. Historisk statistik för Sverige, Demografiska rapporter 1999:2. Örebro: SCB.

Statistics Sweden. (2009) Beskrivning av Sveriges befolkning 2008. Örebro: SCB. 
Statistics Sweden. (2012) Befolkningens utbildning 2012. Örebro: SCB.

Statistics Sweden. (2013a) Andelen äldre fördubblad på 100 år. URL: http://www.scb.se/sv_/Hitta-statistik/Artiklar/Andelen-aldre-fordubbladpa-100-ar/. (Accessed 21.12.2013).

Statistics Sweden. (2013b) Hushållens ekonomi (HEK). Disponibel inkomst per konsumtionsenhet för individer efter ålder samt förändringar i procent, korrigerad 2013-02-18. URL: http://www.scb.se/sv_/Hittastatistik/Statistik-efter-amne/Hushallens-ekonomi/Inkomster-ochinkomstfordelning/Hushallens-ekonomi-HEK/7289/7296/Disponibelinkomst-19912011/28883/. (Accessed 16.12.2013).

Stjernborg, V., Emilsson, U.M. and Ståhl, A. (2014) Changes in outdoor mobility when becoming alone in the household in old age. Journal of Transport \& Health 1: 9-16.

Stjernborg, V., Wretstrand, A. and Tesfahuney, M. (2015) Everyday life mobilities of older persons - A case study of ageing in a suburban landscape in Sweden. Mobilities 10: 383-401.

Ståhl, A., Carlsson, G., Hovbrandt, P., et al. (2008) "Let's go for a walk!": identification and prioritisation of accessibility and safety measures involving elderly people in a residential area. European Journal of Ageing 5: 265-273.

Szinovacz, M.E. (2003) Contexts and pathways: retirement as institution, process, and experience. In: Adams G.A. and Beehr T.A. (eds) Retirement: Reasons, processes, and results. New York: Springer Publishing Company, Inc., 652.

Szinovacz, M.E., DeViney, S. and Davey, A. (2001) Influences of family obligations and relationships on retirement variations by gender, race, and marital status. The Journals of Gerontology Series B: Psychological Sciences and Social Sciences 56: 20-27. 
Sörensen, G. and Hakamies-Blomqvist, L. (2000) Bilkörning på äldre dar - en kvalitativ studie om att åldras som trafikant, VTI notat 83-2000. Linköping: Statens väg- och transportforskningsinstitut.

Taghizadeh Larsson, A. (2009) Att åldras med funktionshinder: betydelser av socialt och kronologiskt åldrande för människor som under lång tid levt med fysiska funktionsnedsättningar. Doctoral Dissertation. Institutionen för samhälls- och välfärdsstudier, Linköping: Linköpings Universitet.

Thelin, A. (2009) Den tredje åldern-en kunskapsöversikt, Rapportserie i socialt arbete. Nr 1, 2009, Växjö universitet.

Thulin, E. and Vilhelmson, B. (2008) Rörlighetens tid. Vinnova slutrapport. Göteborg: Kulturgeografiska institutionen, Göteborgs universitet.

Transport Analysis. (2012) The Swedish national travel survey 2011. Trafikanalys.

Twigg, J. and Majima, S. (2014) Consumption and the constitution of age: expenditure patterns on clothing, hair and cosmetics among post-war 'baby boomers'. Journal of Aging Studies 30: 23-32.

Walford, N., Samarasundera, E., Phillips, J., et al. (2011) Older people's navigation of urban areas as pedestrians: measuring quality of the built environment using oral narratives and virtual routes. Landscape and Urban Planning 100: 163-168.

Walker, A. (2009) Commentary: the emergence and application of active aging in Europe. Journal of Aging \& Social Policy 21: 75-93.

Walker, A. and Foster, L. (2006) Caught between virtue and ideological necessity. A century of pension policies in the UK. Review of Political Economy 18: 427-448.

Van den Bogaard, L., Henkens, K. and Kalmijn, M. (2013) So now what? Effects of retirement on civic engagement. Ageing \& Society 34: 1170-1192. 
Van der Waerden, P., Timmermans, H. and Borgers, A. (2003) The influence of key events and critical incidents on transport mode choice switching behavior- A descriptive analaysis. Paper presented at the 10th International Conference on Travel Behaviour Research: Moving through nets: the physical and social dimensions of travel. Lucerne, 10th-15th August 2003.

Van Solinge, H. and Henkens, K. (2008) Adjustment to and satisfaction with retirement: two of a kind? Psychology and Aging 23: 422-434.

Wang, M. (2007) Profiling retirees in the retirement transition and adjustment process: examining the longitudinal change patterns of retirees' psychological well-being. Journal of Applied Psychology 92: 455-474.

Wang, M., Henkens, K. and van Solinge, H. (2011) Retirement adjustment: a review of theoretical and empirical advancements. American Psychologist 66: 204-213.

Wang, Z. and Lee, C. (2010) Site and neighborhood environments for walking among older adults. Health \& Place 16: 1268-1279.

Wennberg, H., Ståhl, A. and Hydén, C. (2009) Older pedestrians' perceptions of the outdoor environment in a year-round perspective. European Journal of Ageing 6: 277-290.

Verhoeven, M. (2010) Modelling life trajectories and transport mode choice using Bayesian belief networks. Doctoral Dissertation. Urban Planning Group, Faculteit Bouwkunde, Eindhoven: Technische Universiteit Eindhoven.

Verhoeven, M., Arentze, T., Timmermans, H., et al. (2007) Examining temporal effects of lifecycle events on transport mode choice decisions. International Journal of Urban Sciences 11: 1-13.

Westin, K. and Vilhelmsson, B. (2011) Old, yet young: travel-activity patterns among new pensioners in Sweden. Social Space 1: 126-146. 
Whelan, M., Langford, J., Oxley, J., et al. (2006) The elderly and mobility: a review of the literature. Monash University Accident Research Centre Australia.

WHO. (2002) A physically active life through everyday transport. Copenhagen: World Health Organization.

WHO. (2012) Strategy and action plan for healthy ageing in Europe, 2012-2020. Copenhagen: World Health Organization.

Vichitvanichphong, S., Talaei-Khoei, A., Kerr, D., et al. (2015) What does happen to our driving when we get older? Transport Reviews 35: 56-81.

Vij, A., Carrel, A. and Walker, J.L. (2013) Incorporating the influence of latent modal preferences on travel mode choice behavior. Transportation Research Part A-Policy and Practice 54: 164-178.

Vincent, J.A., Phillipson, C. and Downs, M. (2006) The futures of old age. London: Sage.

Wretstrand, A., Svensson, H., Fristedt, S., et al. (2009) Older people and local public transit: mobility effects of accessibility improvements in Sweden. Journal of Transport and Land Use 2: 49-65.

Vrotsou, K. (2010) Everyday mining: exploring sequences in event-based data. Doctoral Dissertation. Institutionen för teknik och naturvetenskap, Norrköping: Linköpings Universitet.

Zegras, C., Lee, J.S. and Ben-Joseph, E. (2012) By community or design? Agerestricted neighbourhoods, physical design and baby boomers' local travel behaviour in suburban Boston, US. Urban Studies 49: 2169-2198.

Zeitler, E. and Buys, L. (2015) Mobility and out-of-home activities of older people living in suburban environments: "Because I'm a driver, I don't have a problem". Ageing \& Society 35: 785-808. 
Ziegler, F. (2012) "You have to engage with life, or life will go away": an intersectional life course analysis of older women's social participation in a disadvantaged urban area. Geoforum 43: 1296-1305.

Ziegler, F. and Schwanen, T. (2011) "I like to go out to be energised by different people": an exploratory analysis of mobility and wellbeing in later life. Ageing \& Society 31: 758-781. 
Appendix 1

Letter to informants 2011, in Swedish

Hej,

Jag som skriver detta brev är transportforskare från VTI (Statens Väg- och transportforskningsinstitut) i Linköping. I höst kommer jag att göra en studie om hur övergången från arbetsliv till pension påverkar vardagens resor.

Jag vill nu komma i kontakt med dig som nyligen har gått i pension för att få veta lite mer om hur du reser i din vardag. Hur reser du till dina fritidsaktiviteter och för att göra dina ärenden? Hur upplever du att resorna fungerar? Hur har resorna förändrats genom åren? Vilka för- och nackdelar tycker du tycker att din bostadsort har för att dina resor ska fungera?

Min studie går ut på att man fyller i sina resor i en dagbok under en veckas tid. Detta tar ingen särskild tid i anspråk efter som man i punktform fyller i när, var och hur man reser i en färdig mall. Denna dagbok följs sedan upp av en intervju som tar ca en timme. Intervjun kommer att äga rum under oktober månad.

Om du vill vara med, eller vill veta mer om studien, vänligen hör av dig till mig så kan vi boka in en tid för intervju som passar dig. Se kontaktuppgifter nedan. Som ett litet tack för hjälpen för ditt deltagande kommer du att få ett presentkort $i$ en närliggande mataffär.

Vänliga hälsningar

Jessica Berg, VTI

Telefon: $\quad 013-204024$

E-post: jessica.berg@vti.se 


\section{Appendix 2}

Instructions for travel diary, in Swedish

Tack för att du vill vara med i VTI:s studie om vardagens resor som nyligen pensionerad. Här kommer resedagboken och instruktioner för hur den ska fyllas i. Varje resa ska fyllas i på en rad.

Från måndag 3 oktober- söndag 9 oktober- notera alla dina resor du gör utanför hemmet. Med resor menar jag alla förflyttningar till fots, med cykel, kollektivtrafik, bil och andra motorfordon (även skjuts med bil och taxi).

Start- och sluttid: Notera ungefärligt klockslag när du går/åker och när du är framme - inte enbart förmiddag/eftermiddag.

Från och till: Varifrån går/åker du och var ska du? Notera om du går/åker hemifrån eller från landet, badhuset, stormarknaden etc och var du ska. OBS! Om du går/åker hemifrån till t.ex. affären fyller du i det på en rad. Om du sedan går/åker från affären så blir det en ny rad oavsett om du ska hem eller någon annanstans. Om du däremot tar en promenad i skogen eller en motionsrunda, notera enbart den eventuella transporten dit och tillbaka.

Syfte: Notera här det huvudsakliga syftet med resan ex. skjutsa frun till träningen, hämta en äldre släkting för att skjutsa henne/honom till vårdcentralen, tar en tur med bilen för nöjes skull etc.

Färdsätt: Till fots, bil, cykel, spårvagn, moped osv. Notera också om du använder fler färdsätt, t.ex. cyklar till bussen. Då skriver du cykel och buss i samma kolumn.

Tillsammans med: Om du går/åker med maka/make, vem du blir hämtad av eller hämtar upp på vägen.

Tankar/Känslor: Vissa dagar ser man fram emot att gå/åka iväg, andra dagar vill man bara stanna hemma. Fyll i här hur du tänker och känner just inför den specifika resan.

Orsak till inställda resor: Hade du tänk att gå/åka en dag men stannade hemma, notera eventuell anledning (dåligt väder, hälsan etc.) 


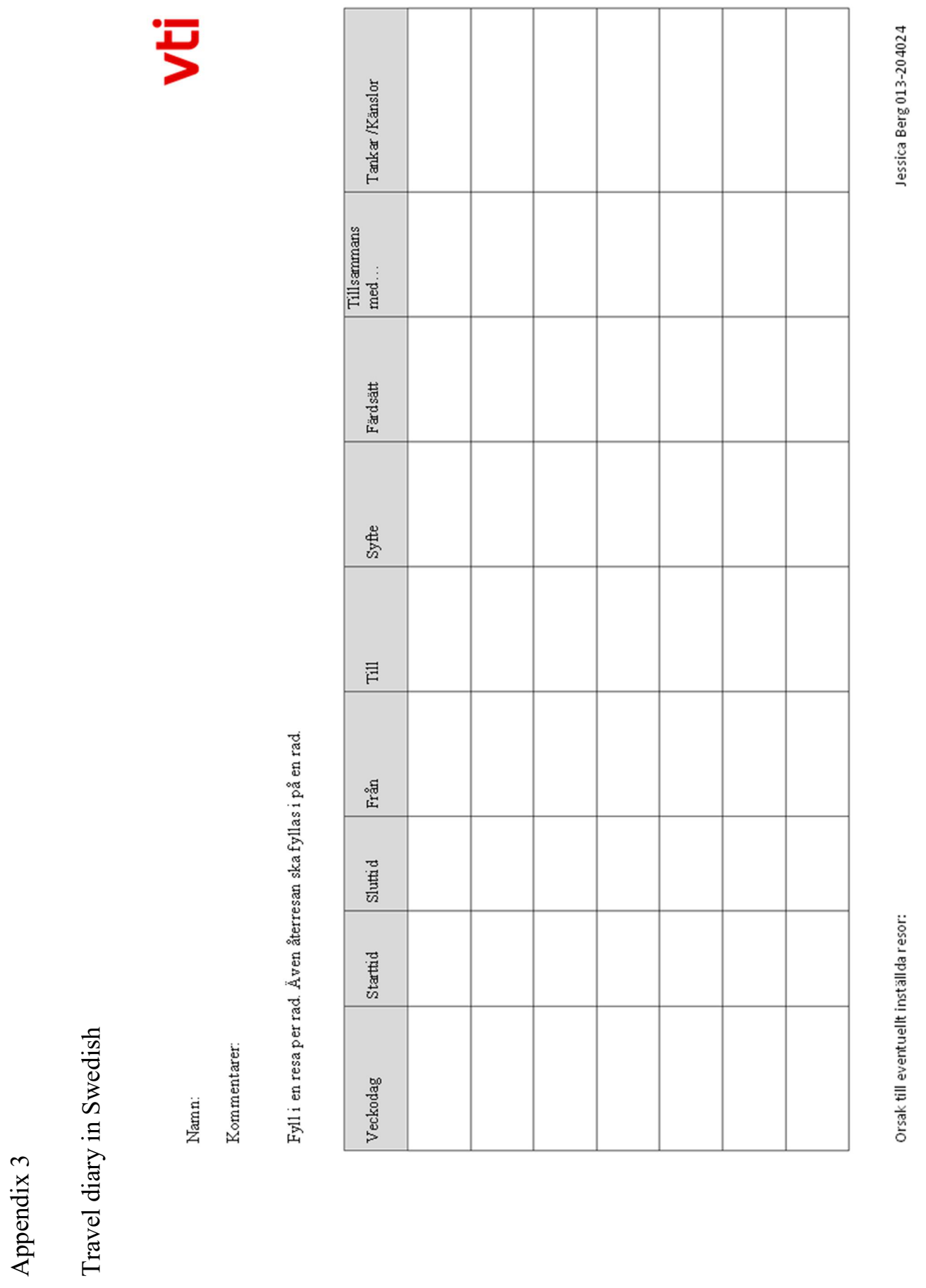




\section{Appendix 4}

Interview guide in Swedish 2011

\begin{tabular}{|c|c|}
\hline $\begin{array}{l}\text { Resande i } \\
\text { allmänhet }\end{array}$ & 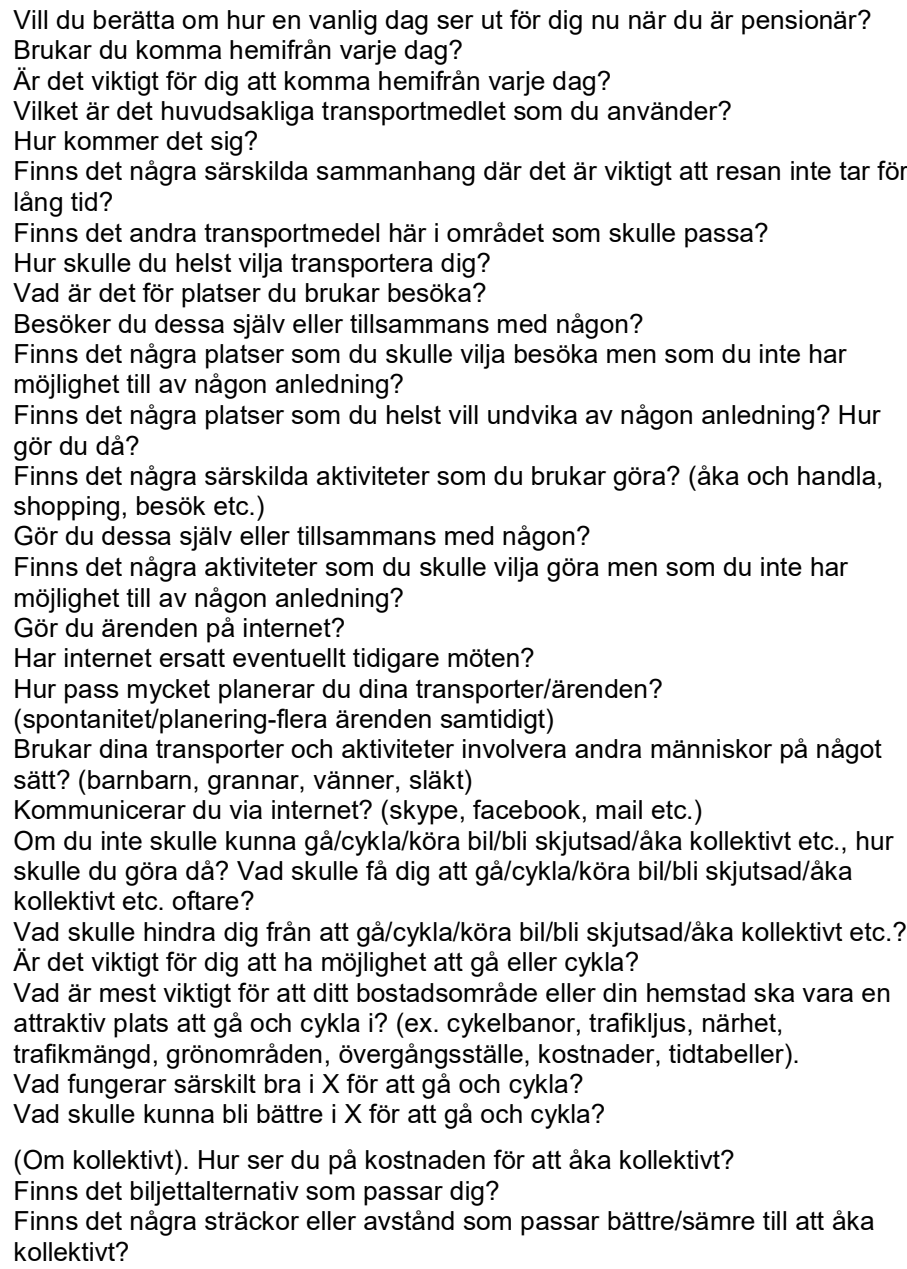 \\
\hline $\begin{array}{l}\text { Bostadsområde } \\
\text { och boende }\end{array}$ & $\begin{array}{l}\text { Hur påverkas dina möjligheter till att komma ut av att du bor här i X? } \\
\text { Hur påverkar } X \text { möjligheten att gå och cykla? } \\
\text { Vilka för- och nackdelar finns med ditt boende när det gäller att komma ut? } \\
\text { Hur tänker du om ditt boende i framtiden? } \\
\text { Vilka alternativ finns? }\end{array}$ \\
\hline
\end{tabular}




\section{Appendix 4}

Interview guide in Swedish 2011

\begin{tabular}{|c|c|}
\hline $\begin{array}{l}\text { Resor som } \\
\text { förälder }\end{array}$ & $\begin{array}{l}\text { (om barn) Hur såg det ut när barnen var små? } \\
\text { Bodde du här då? } \\
\text { Var arbetade du? } \\
\text { Hur mycket arbetade du? } \\
\text { Hur reste du till arbetet? } \\
\text { Vilka aktiviteter brukade du/ni ha? }\end{array}$ \\
\hline $\begin{array}{l}\text { Pensionering i } \\
\text { allmänhet }\end{array}$ & $\begin{array}{l}\text { Hur var/är den första tiden som pensionär? } \\
\text { Innan pensioneringen - hur tänkte du om att gå i pension? } \\
\text { Hade du några planer för vad du skulle göra som pensionär? } \\
\text { Hur tänker du kring detta? (med att planera) }\end{array}$ \\
\hline Tiden & $\begin{array}{l}\text { När man arbetar kan man ofta uppleva att tiden inte räcker till allt man vill } \\
\text { göra på fritiden. } \\
\text { Hur upplever du tiden nu när du är pensionär? } \\
\text { Finns det några särskilda händelser/förändringar i livet som har påverkat din } \\
\text { användning av tid? (gett dig mer eller mindre tid att spela med) }\end{array}$ \\
\hline $\begin{array}{l}\text { Övrigt } \\
\text { informanten vill } \\
\text { tillägga? }\end{array}$ & \\
\hline $\begin{array}{l}\text { Frågor kring } \\
\text { dagboken }\end{array}$ & $\begin{array}{l}\text { Skulle du säga att detta är en ganska vanlig vecka? } \\
\text { Vad skiljer? } \\
\text { Vad är typiskt? } \\
\text { Finns det några platser som skulle vilja ha besökt denna vecka som du inte } \\
\text { besökte? } \\
\text { Finns det några aktiviteter som du av någon anledning inte gjorde som du } \\
\text { hade velat göra? (hunnit med det man hade tänkt?) } \\
\text { Om en viss känsla har infunnit sig för en särskild resa - be informanten } \\
\text { berätta om det. } \\
\text { Om en resa verkar komplicerad eller lång t.ex. eller om informanten har gjort } \\
\text { ovanligt många resor en viss dag - fråga om resan/resorna skulle kunna ha } \\
\text { genomförts på annat sätt eller vid andra tidpunkter? }\end{array}$ \\
\hline
\end{tabular}




\section{Appendix 5}

Letter to informants 2015, in Swedish

Hej,

I oktober 2011 intervjuade jag dig om hur du transporterar dig och om vardagen som nybliven pensionär. Intervjuerna som jag gjorde då och resdagboken som du fyllde i har gett ny kunskap om hur första tiden som pensionär är och hur transporterna påverkas men vi behöver veta mer om hur det blir sen, när vardagslivet som pensionär har "satt sig". Därför skulle jag nu vilja göra en uppföljningsintervju med dig. Denna gång är det bara en intervju jag vill göra, inte en resedagbok som du fyllde i sist.

Jag är tacksam om du kan tänka dig att ställa upp på en sådan uppföljningsintervju. Intervjun kommer ungefär att vara i 45 minuter.

I så fall kan antingen du kontakta mig så bokar vi in en tid som passar dig eller så ringer jag upp inom de närmsta dagarna. Som ett litet tack för hjälpen för ditt deltagande kommer du återigen att få ett presentkort i en närliggande mataffär.

Vänliga hälsningar

Jessica Berg, Statens väg- och transportforskningsinstitut, VTI

Telefon: 013-20 4024

E-post: jessica.berg@vti.se 


\section{Appendix 6}

Interview guide in Swedish 2015

\begin{tabular}{|l|l|}
\hline Pensionering i allmänhet & $\begin{array}{l}\text { När vi pratades vid sist nämnde du att det var } \\
\text { skönt/långtråkigt/xx att vara pensionär? Hur tänker du kring } \\
\text { det idag? } \\
\text { Finns det några särskilda händelser som har påverkat din } \\
\text { vardag sedan du gick i pension? (följ upp sedan vid frågor } \\
\text { om resor och aktiviteter). }\end{array}$ \\
\hline Aktiviteter & $\begin{array}{l}\text { Om du jämför med hur det var när du precis hade gått i } \\
\text { pension, har du fler eller färre aktiviteter idag? } \\
\text { Har du några nya aktiviteter eller några som du har slutat } \\
\text { med? }\end{array}$ \\
\hline Mobilitet i allmänhet & $\begin{array}{l}\text { Vill du berätta om hur en vanlig dag ser ut för dig nu när du är } \\
\text { pensionär? } \\
\text { Brukar du komma hemifrån varje dag? } \\
\text { Är det viktigt för dig att komma hemifrån varje dag? } \\
\text { Det är nu drygt 3 år sedan vi pratade vid sist. Då berättade } \\
\text { du att } \\
\text { Hur skulle du säga att det ser ut idag? Använder du } \\
\text { fortfarande bilen/cykeln/går varje dag? } \\
\text { Hur kommer det sig? } \\
\text { Om du jämför med hur det var när du precis hade gått i } \\
\text { pension, gör du fler eller färre resor idag? Hur kommer det } \\
\text { sig? } \\
\text { Finns det några särskilda sammanhang där det är viktigt att } \\
\text { resan inte tar för lång tid? } \\
\text { Hur skulle du helst vilja transportera dig? } \\
\text { Gör du ärenden på internet? } \\
\text { Har internet minskat dina resor? } \\
\text { Hur pass mycket planerar du dina transporter/ärenden? } \\
\text { (spontanitet/planering-flera ärenden samtidigt) } \\
\text { Är det viktigt för dig att ha möjlighet att gå eller cykla? }\end{array}$ \\
\hline
\end{tabular}




\section{Appendix 6}

Interview guide in Swedish 2015

\begin{tabular}{|c|c|}
\hline & $\begin{array}{l}\text { Pensionärspris på bussarna gäller numera från } 65 \text { år. Hur } \\
\text { ofta åker du buss eller spårvagn? } \\
\text { Tror du att priset kommer påverka din användning av } \\
\text { kollektivtrafiken framöver? }\end{array}$ \\
\hline $\begin{array}{l}\text { Om partner har gått i } \\
\text { pension sedan sist }\end{array}$ & $\begin{array}{l}\text { Vad har varit den största förändringen när ni blev pensionärer } \\
\text { båda två? } \\
\text { Om ni tänker på ärenden eller aktiviteter som ni hade när din } \\
\text { fru/make fortfarande arbetade (såsom att handla, motionera, } \\
\text { besöka vänner och släkt etc.). } \\
\text { Gör ni sådana resor lika ofta eller mer sällan? Andra tider? } \\
\text { Helger/i veckan? } \\
\text { Hade ni planer på vad ni skulle göra när båda hade blivit } \\
\text { pensionärer? Hur har det blivit? }\end{array}$ \\
\hline Aspekter av tidsanvändning & $\begin{array}{l}\text { Idag pratar man ofta om att människor ska få ihop sitt } \\
\text { livspussel. Hur ser ditt livspussel ut? } \\
\text { Om du har många saker du behöver göra, delar du upp det } \\
\text { eller försöker du göra så mycket som möjligt under en dag? } \\
\text { Är det viktigt för dig att ha en inrutad dag men vissa tider } \\
\text { bestämda? }\end{array}$ \\
\hline Bostadsområde och boende & $\begin{array}{l}\text { (om de har flyttat sedan sist): Hur påverkas dina möjligheter } \\
\text { till att komma ut av att du bor här i X? } \\
\text { Hur påverkar X möjligheten att gå och cykla? } \\
\text { Vilka för- och nackdelar finns med ditt boende när det gäller } \\
\text { att komma ut? } \\
\text { Har du funderat på hur du vill bo i framtiden? }\end{array}$ \\
\hline $\begin{array}{l}\text { Något övrigt som } \\
\text { informanten vill tillägga? }\end{array}$ & \\
\hline
\end{tabular}





\section{Papers}

The articles associated with this thesis have been removed for copyright reasons. For more details about these see:

http://urn.kb.se/resolve?urn=urn:nbn:se:liu:diva-124664 